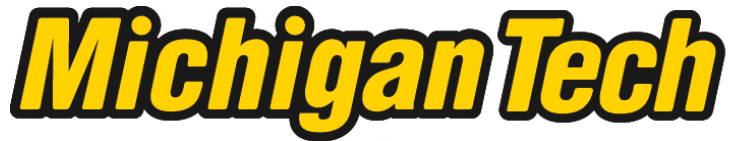 \\ Michigan Technological University Create the Future Digital Commons @ Michigan Tech
}

\section{Quincy and Torch Lake Railroad engine house facility management and interpretive plan}

Dennis H. Leopold

Michigan Technological University

Follow this and additional works at: https://digitalcommons.mtu.edu/etds

Part of the Environmental Policy Commons

Copyright 2011 Dennis H. Leopold

\section{Recommended Citation}

Leopold, Dennis H., "Quincy and Torch Lake Railroad engine house facility management and interpretive plan", Master's report, Michigan Technological University, 2011.

https://doi.org/10.37099/mtu.dc.etds/569

Follow this and additional works at: https://digitalcommons.mtu.edu/etds

Part of the Environmental Policy Commons 


\title{
QUINCY AND TORCH LAKE RAILROAD ENGINE HOUSE FACILITY MANAGEMENT AND INTERPRETIVE PLAN
}

\author{
By \\ DENNIS H. LEOPOLD
}

\author{
A PROJECT \\ Submitted in partial fulfillment of the requirements \\ for the degree of \\ MASTER OF SCIENCE IN INDUSTRIAL ARCHAEOLOGY
}

MICHIGAN TECHNOLOGICAL UNIVERSITY

2011

(C) 2011 Dennis H. Leopold 
This report, "The Quincy \& Torch Lake Railroad Management and Interpretive Plan" is hereby approved in partial fulfillment of the requirements for the Degree of MASTER OF SCIENCE IN INDUSTRIAL ARCHAEOLOGY.

DEPARTMENT:

Social Sciences

Signatures:

Report Advisor

Patrick E. Martin

Department Chair

Patrick E. Martin

Date 


\begin{abstract}
The "Quincy \& Torch Lake Railroad Engine House Facility Management and Interpretive Plan" was designed to serve as a guide to aid the Quincy Mine Hoist Association in their efforts to restore and interpret historic railroad resources under their stewardship. Early searches for existing management and interpretive plans demonstrated that similar plans were primarily produced by the National Park Service and were intended to guide large scale heritage sites that consist of a variety of cultural resources. This project adapts concepts found in those large scale management and interpretive site plans, to guide small scale site management, restoration, and interpretive projects. The document presents a three stage, second phase restoration process. Each stage of development is guided by a series of management and interpretive goals and objectives which were set for the engine house facility.
\end{abstract}




\section{$\underline{\text { Table Of Contents }}$}

Introduction $\quad 5$

Historic Background 9

Project Area 16

Engine House Facility 22

Current Conditions 31

Management Plan 35

Statements of Significance $\quad 35$

Mission Statement $\quad 36$

Considerations and Influences $\quad 37$

Resource Inventory $\quad 39$

Engine House Facility 39

Extant Equipment 42

Miscellaneous Features $\quad 42$

Informational Resources $\quad 45$

Management/Interpretive Resources $\quad 46$

Community Resources $\quad 46$

Engine House Goals and Objective 46

Goals and Objectives $\quad 46$

Development Stages 48

Engine House Facility 49

Current Status 49

Development Stage 1

Development Stage $2 \quad 50$

Development Stage $3 \quad 50$

Interpretive Plan 53

Interpretation 53

Interpretive and Thematic Objectives $\quad 55$

Interpretive Themes $\quad 55$

Primary Theme 56

Sub-themes $\quad 56$

Visitor Profile $\quad 57$

Visitor Experience $\quad 58$

Engine House Facility Interpretive Trail 59

Outcomes and Further Options 62

Before Arriving 62

Engine House 62

Further Options 63

Conclusion 64

Bibliography $\quad 65$

Appendix

Interpretive Panels 68 


\section{$\underline{\text { Introduction }}$}

Quincy Mine Hoist Association (QMHA) owns approximately 250 acres of former Quincy Mining Company (Figure1) land and more than twenty buildings and ruins of the former mining company's industrial core. Originally QMHA was organized to preserve the Quincy Mining Company Number 2 hoist; they hoped to restore the hoist, the Number 2 shaft house, a miner's village, and the Quincy \& Torch Lake Railroad. In 1966 QMHA began leasing what is the main exhibit area, and includes the No. 2 hoist building, the No. 2 shaft house, supply house, and ancillary structures from Quincy Mining Company (By-laws 1958, Veeser 1966). Plans to restore the village and railroad were abandoned due to related expenses. QMHA has grown considerably since the hoist building first opened for tours in 1968, and today conducts guided and self-guided interpretive tours at several locations on the property. However, it recognizes the need to expand interpretation beyond the hoist, shaft house, and mine.

In 1995 Heather Spencer, a graduate student in MTU's Industrial Archaeology program, created a Quincy Mining Company interpretive plan and designed a series of interpretive trails for the Quincy National Historic Landmark . The plan include a number of wayside panels placed at key locations along paths that were to wind their way through the former mining company property. At that time much of the land was leased from Quincy Mining Company’s successor, Quincy Development Corporation. (Spencer 1995) Interpretive panels seemed an option requiring a minimal investment for leased property beyond the Number 2 Hoist and Shaft House Exhibit. The former Quincy \& Torch Lake Railroad engine house was included in that interpretive plan. The plan however, was not implemented.

By 2000 QMHA owned most of the land recognized as the industrial core of the mine site and started to expand its interpretive program. Edward Yarborough, QMHA manager, re-kindled interest in partially rehabilitating the Quincy \& Torch Lake Railroad, 


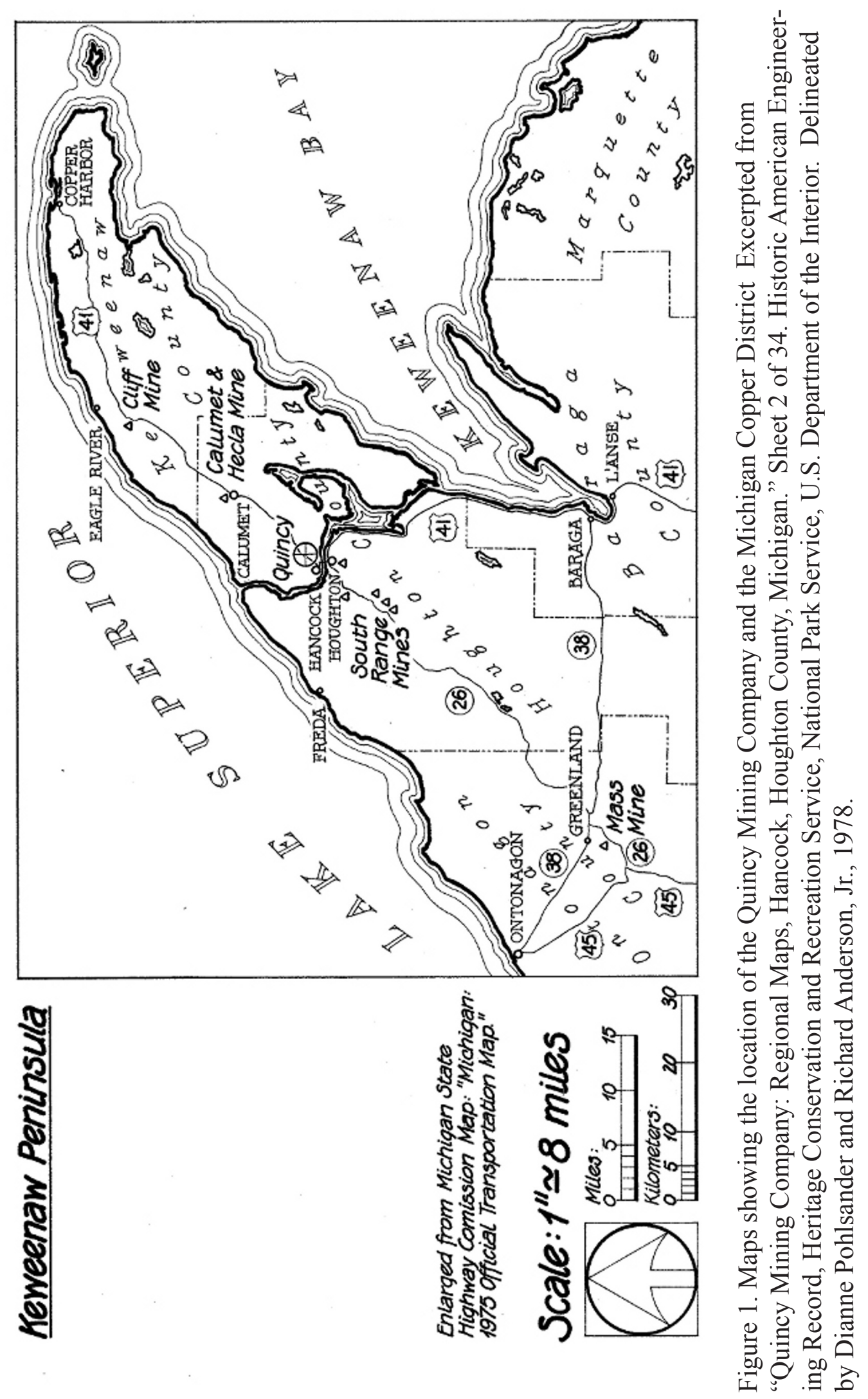


focusing initially on the engine house. The project gained momentum and following his departure in 2008, members of the Board of Directors continued his work. In 2009, nearly a decade after Yarborough initiated the project, Craig Wilson and fellow archaeologists from Michigan Technological University’s Industrial Archaeology program conducted an archaeological investigation at the engine house site, supported by a Transportation Enhancement grant administrated by the State of Michigan. They cleared the structure of vegetation and conducted a survey, recording major features discovered during excavation (Wilson 2009). Work was completed within the walls of the 120-year-old building later that summer, and a report was drawn up, presenting QMHA with the results of the archaeological work in two volumes. This report provided an outline for restoration standards and practices, intended to guide rehabilitation, conservation, and interpretive work at the site. The report emphasized a need for an indepth engine house facility management plan.

Today QMHA has taken steps to begin restoring the Q\&TLRR Engine House Facility and is investing time and money into structural work and interpretive planning at the site (Figure 2). The current report "Quincy \& Torch Lake Railroad Engine House Management and Interpretive Plan" organizes information from previous works into a standard format modeled on National Park Service management and interpretive plans. It will help guide QMHA decision-making processes regarding restoration, future use, and interpretation planning at the engine house through a formatted management and interpretive plan. It can also serve as a model to be used by QMHA for future restoration and interpretive projects at other locations on the property as well.

The "Quincy \& Torch Lake Railroad Engine House Management and Interpretive Plan" is divided into two sections. The first section, "Management Plan," addresses goals and objectives for the site and provides strategies for meeting them. It identifies various considerations and influences at the engine house facility, suggests solutions for 


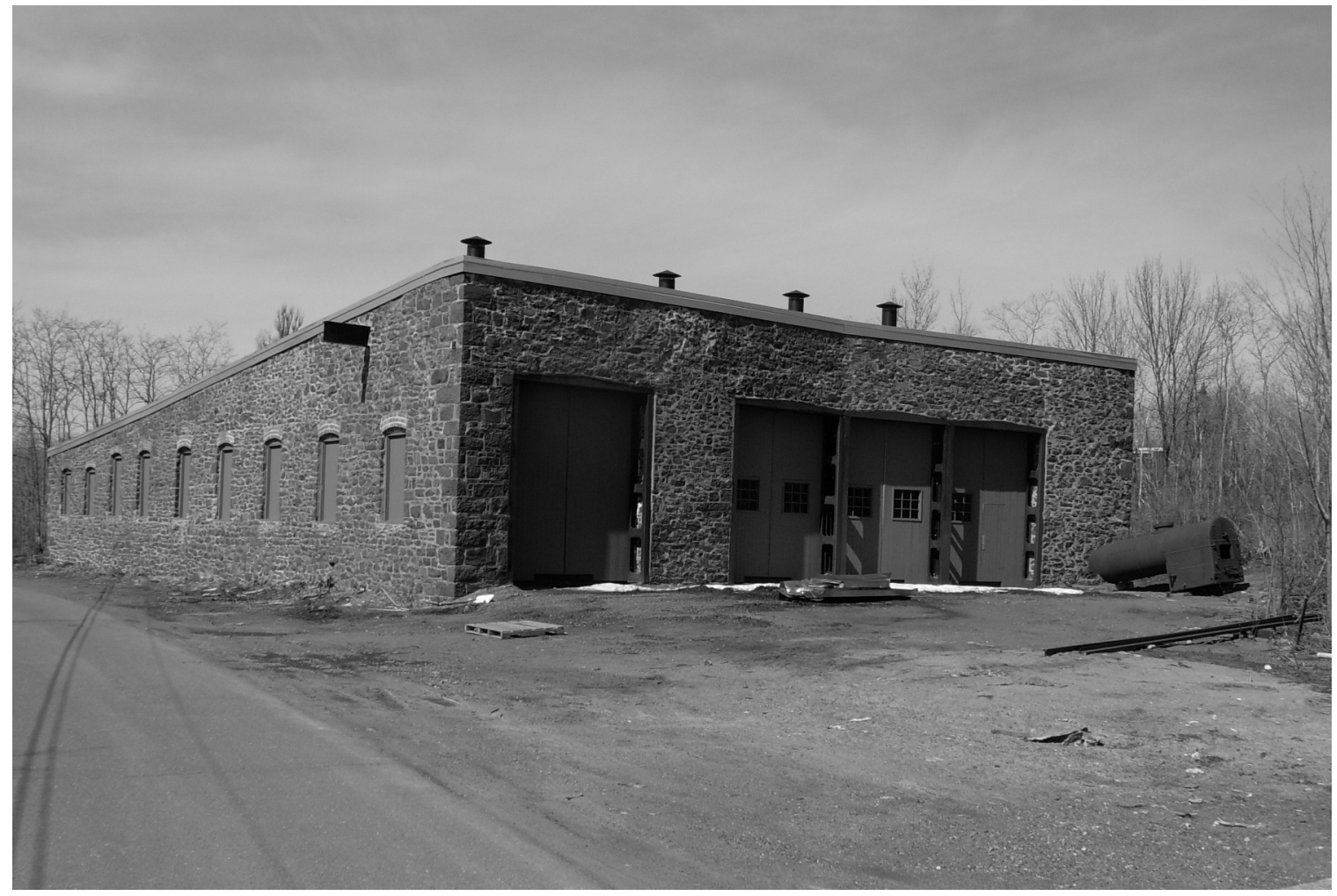

Figure 2. The Quincy \& Torch Lake Railroad engine house as of April 2011. New roof, doors, and window coverings have been installed. Photo by Dennis H. Leopold. 
mediating or overcoming those concerns, and identifies goals and objectives to provide a framework for planning restoration work as it moves forward. The second section, "Interpretive Plan," outlines interpretive objectives, explores various thematic options, and provides suggestions for implementation. To demonstrate an implementation option, the plan includes a suggested interpretive walking trail. In addition an appendix provides suggested interpretive panel texts for various components of the Engine House Facility. This management and interpretive plan was developed in conjunction with staff members from Keweenaw National Historical Park, Quincy Mine Hoist Association, and the Michigan Technological University Department of Social Sciences graduate program in Industrial Archaeology.

\section{Historical Background}

An operational mine maintains a complex system of production, laden with interrelated components including workforce, processing, and transportation. Of the hundreds of copper mines that once existed in Michigan's Copper Country, Quincy Mining Company was one of the longest lived, maintaining a corporate presence in the area into the 1980s (Lankton 1982, 147). Many of the artifacts of production remain largely intact with all major components observable on the landscape. For example, QMHA's main exhibit area preserves a hoisting facility, shaft/rock house, boiler house, mine, worker housing, railroad. The smelter complex and remnants of the Torch Lake stamp mill still exist, but are not owned by QMHA.

Each component of production was closely tied to the others, and the overall success of the company hinged on the smooth operation of the entire system. Transportation networks were simple, but important early in Quincy Mining Company's history and as the mine began to incorporate increasingly complex methods of production, the transportation system had to adapt to keep up (Figure 3).

In 1879 Quincy Mining Company introduced a mechanical rock drill from the Rand 
Drill Company. Nicknamed the "Little Giant," the new drill rapidly replaced the old manual, hand-held drilling method employed underground at the time (Lankton 1982, 59). Within a few years nitroglycerin-based dynamite replaced black powder to blast native copper bearing rock free of the bedrock, and a literal explosion in production occurred as a result.

The increased rock coming from the mine quickly overwhelmed the company's tram road and stamp mill on Portage Lake and soon mill waste began threatening the navigability of the lake by slowly filling it in with mill tailings or stamp sand. By the mid-1880s the Federal Government was strongly urging Quincy Mining Company to relocate its mill due to the stamp sand problem(O'Connell 1978, 594). Quincy began building a new milling facility six miles from the mine on Torch Lake in 1887 (Figure 3).

The old tram-road was outdated and would not be able to serve the new mill, therefore Quincy began exploring the use of local railroads to transport its copper rock to the Torch Lake milling facility. The Mineral Range Railroad already accessed the Quincy property, but its proposed rate for transporting Quincy's product was cost prohibitive at 25 cents per ton. Quincy had estimated a cost of less than 18 cents per ton and began exploring the feasibility of operating its own railroad (O'Connell 1978, 643). Final negotiations with Mineral Range failed, and Quincy began construction of the Quincy \& Torch Lake Railroad in the fall of 1888 (Figure 4). Crews began laying rails in the spring of 1889 and started transporting copper rock to the new mill in 1890 when it was fully operational (O'Connell 1978, 564). The Quincy \& Torch Lake Railroad, wholly owned and exclusively used by the mining company to haul its copper rock between the mine and mill (Figures 5,6), never sought outside sources of revenue. As an integral part of the mining company's production system, the railroad remained significant to the company's success until the end of underground operations in 1945. 


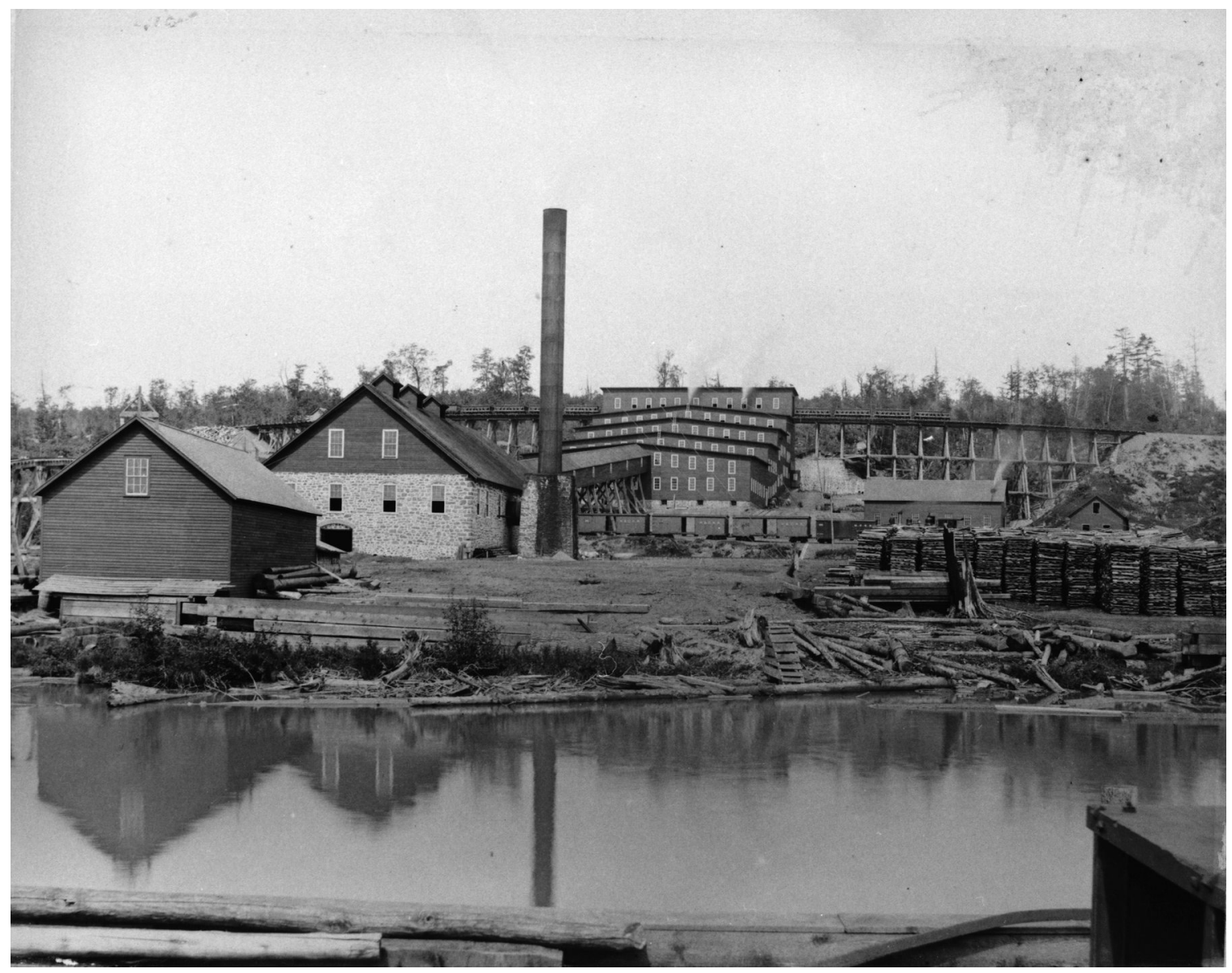

Figure 3. The Quincy Mining Company built the railroad to haul rock from the mine to the company's stamp mill on Torch Lake. Empty rock cars frequently returned filled with coal for the boilers at the mine. Coal was delivered by boat at the mining company's lake front coal dock. Photo courtesy of Historic American Engineering Record, HAER MI-2146. 


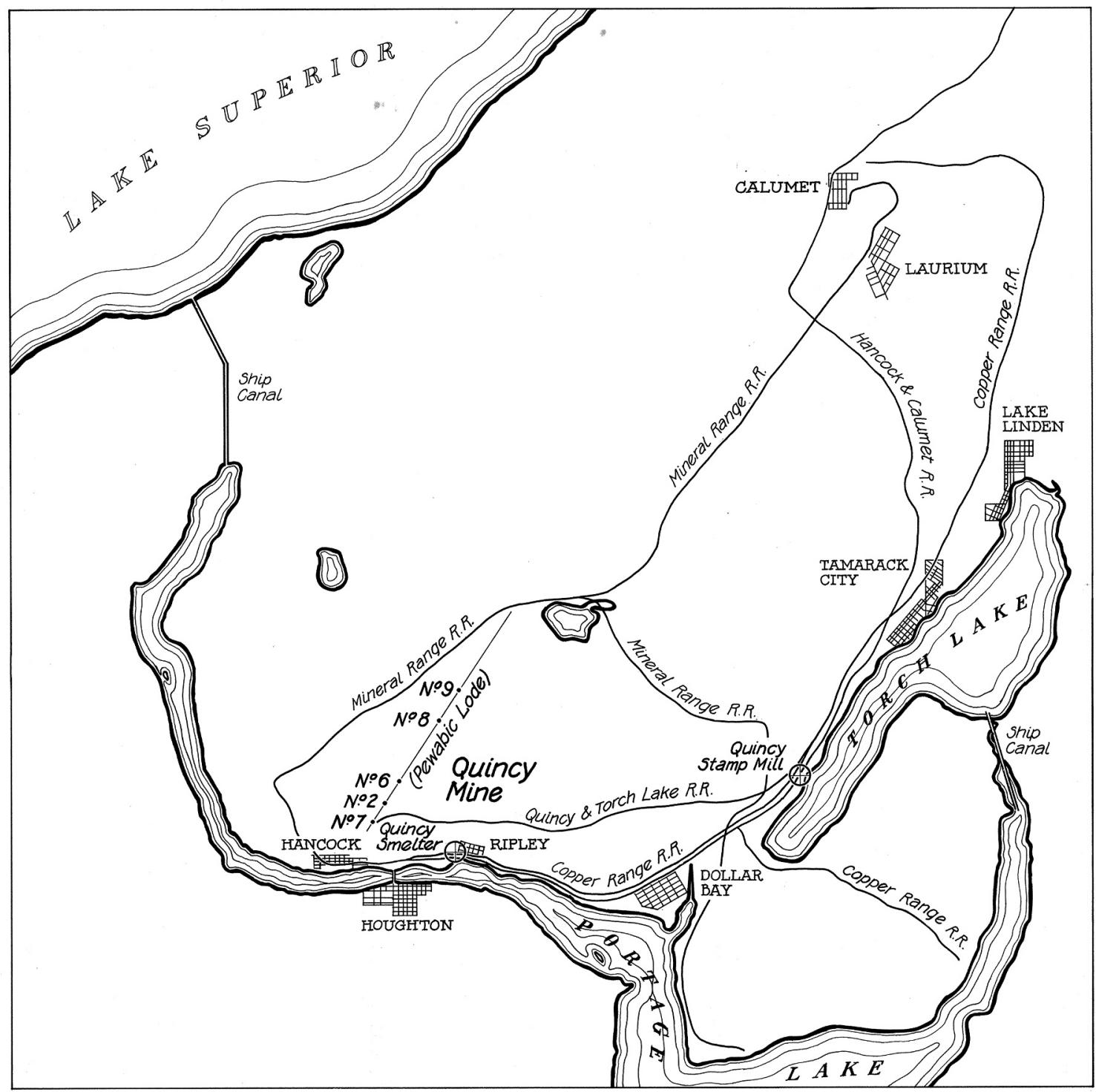

\section{Quincy Mining Company Locality}

Based on Map published with 1910 Annual Report of QMC:

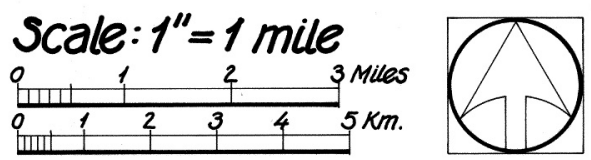

Figure 4. Map showing the location of the Quincy Mining Company and the Michigan Copper District Excerpted from "Quincy Mining Company: Regional Maps, Hancock, Houghton County, Michigan." Sheet 2 of 34. Historic American Engineering Record, Heritage Conservation and Recreation Service, National Park Service, U.S. Department of the Interior. Delineated by Dianne Pohlsander and Richard Anderson, Jr., 1978. 


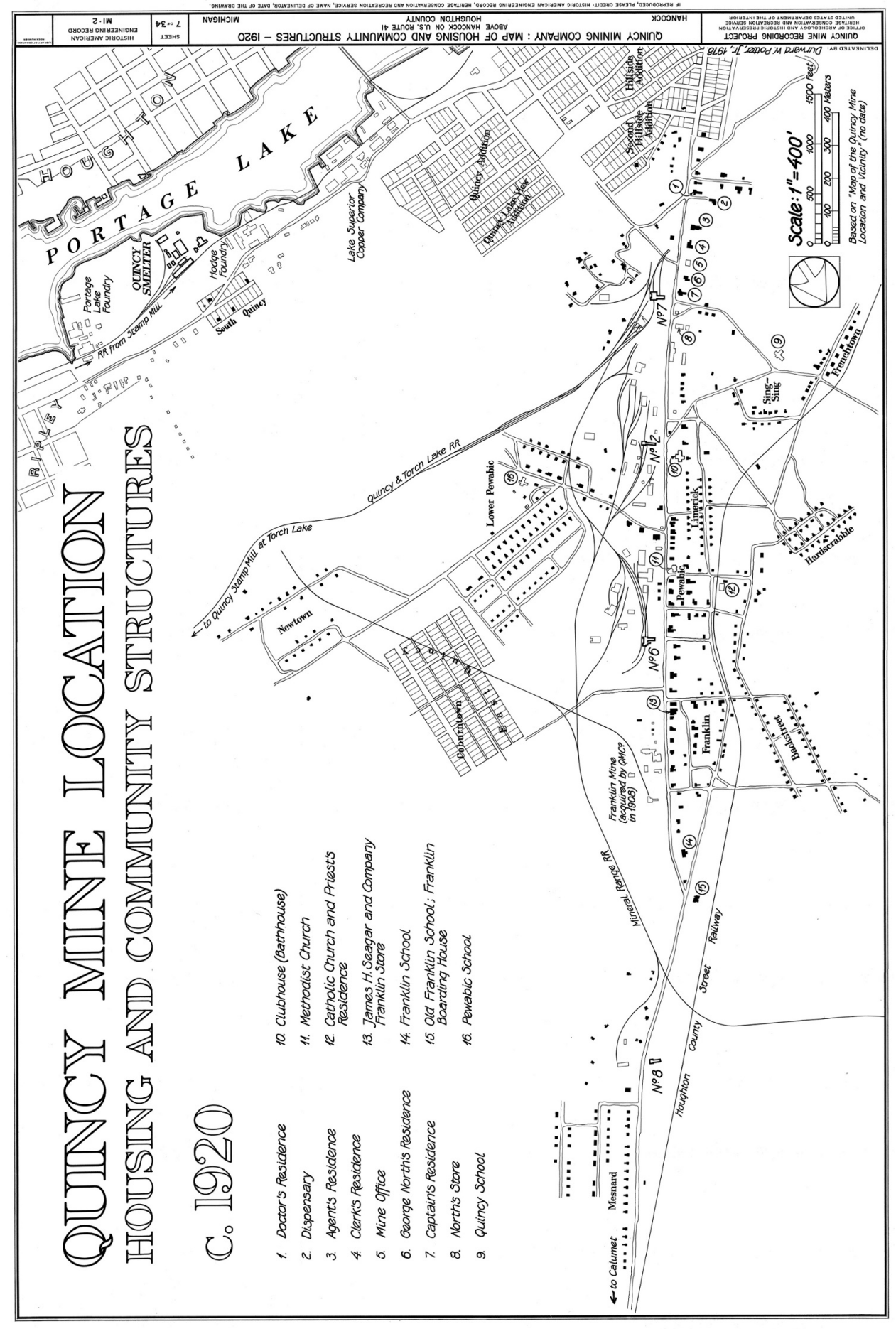

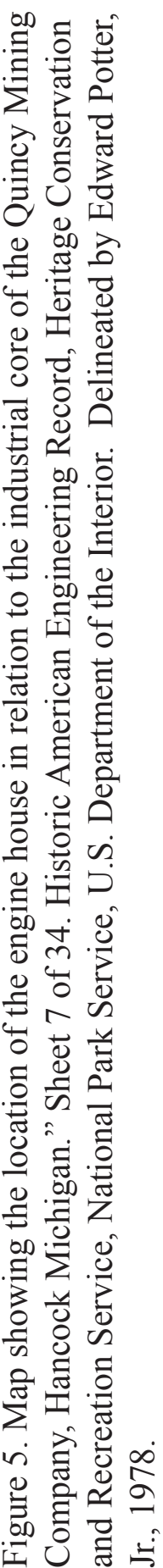




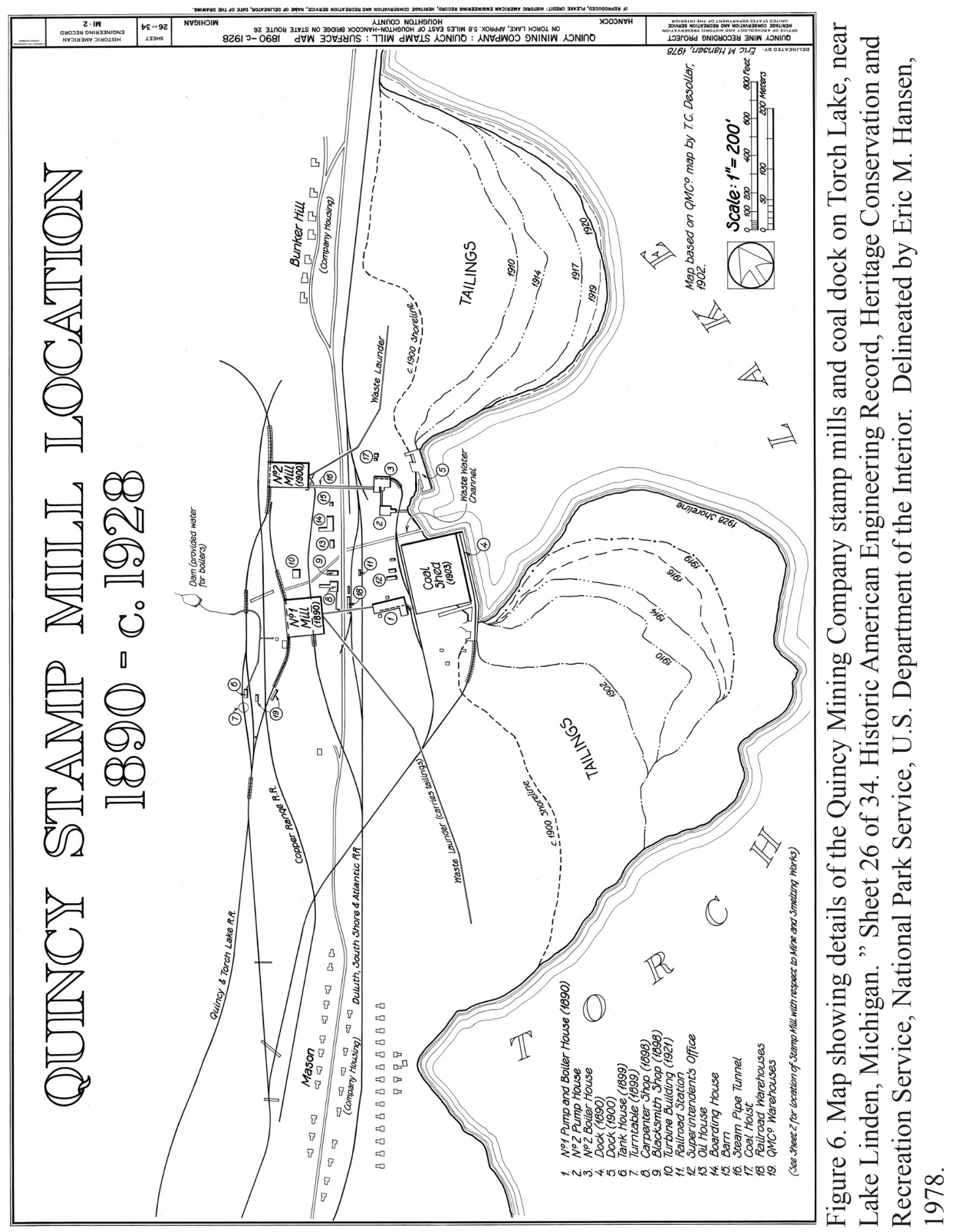




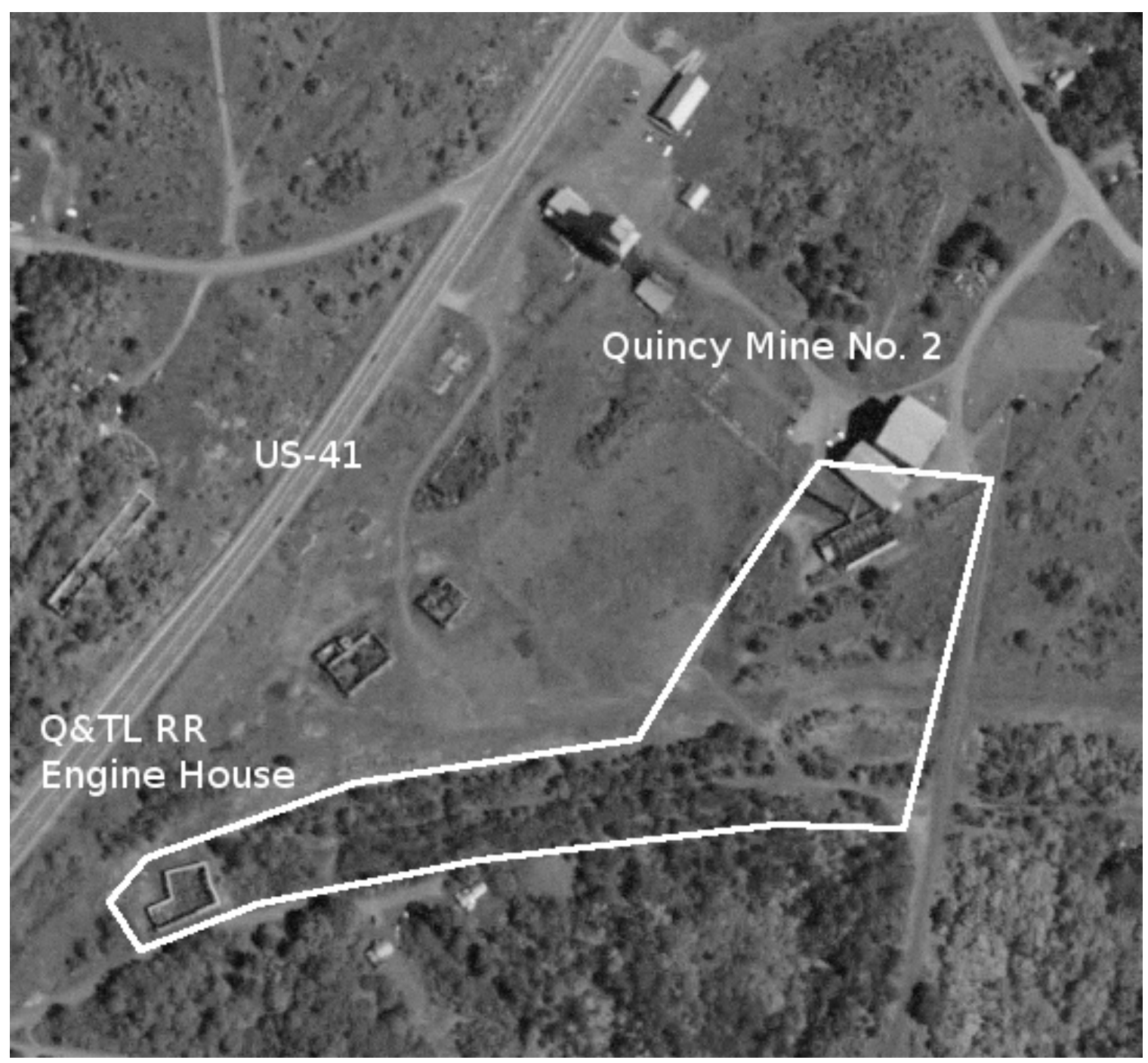

Figure 7. Quincy \& Torch Lake Railroad Engine House Facility Project Area. The white line outlines the project area and includes the locomotive engine house, water tower, and coal stage at the Quincy No. 5 boiler house. Photo Michigan Georef NAIP Digital Ortho Photo Image, Remote Sensing \& GIS Research and Outreach Services (RS\&GIS), Michigan State University. 


\section{Project Area}

The Quincy \& Torch Lake Railroad Engine House Facility, defined for the purposes of this project, consists of roughly four acres of land between the QMHA cog-wheel tram road and the Q\&TLRR Engine House and includes three extant structures and several landscape features associated with the rail yard and grades (Figure 7). The ground surface in this area slopes to the south on a slight grade and is heavily vegetated with brush and small trees. Structures in the project area include the railroad's engine house, water tower, and coal stage at the No. 5 boiler house (Figures 2, 8, 9). They are in various states of disrepair, and all are being considered for further restoration and rehabilitation work; some of this work has already begun.

During the summer of 2010, with financial assistance from a Michigan Department of Transportation Enhancement grant and matching money, QMHA completed the first phase of a restoration project at the Quincy \& Torch Lake Railroad engine house. The grant and matching funds covered an archaeological investigation and structural work including the replacement of all doors, window coverings, roof, and masonry work for the engine house (Figure 10); it also covered some basic stabilization work on the water tower. These two structures sit on the western and northern boundaries of the project area.

The rail yard immediately in front of the engine house defines the southern boundary of the facility and runs eastwards along Roundhouse Road and the crest of the hillside; it terminates, for the purpose of this project, at the grade of Quincy Mine Hoist Association's cog-wheel tram road. The railroad grades exist on different elevations on the sloping hillside and are accessible through a series of gentle transitional grades between the branch line heading to the mine and the engine house facility and the rail yard, reflecting a bit of complexity in the handling of rock and coal trains between the main line and the mine branch (Figure 11). 


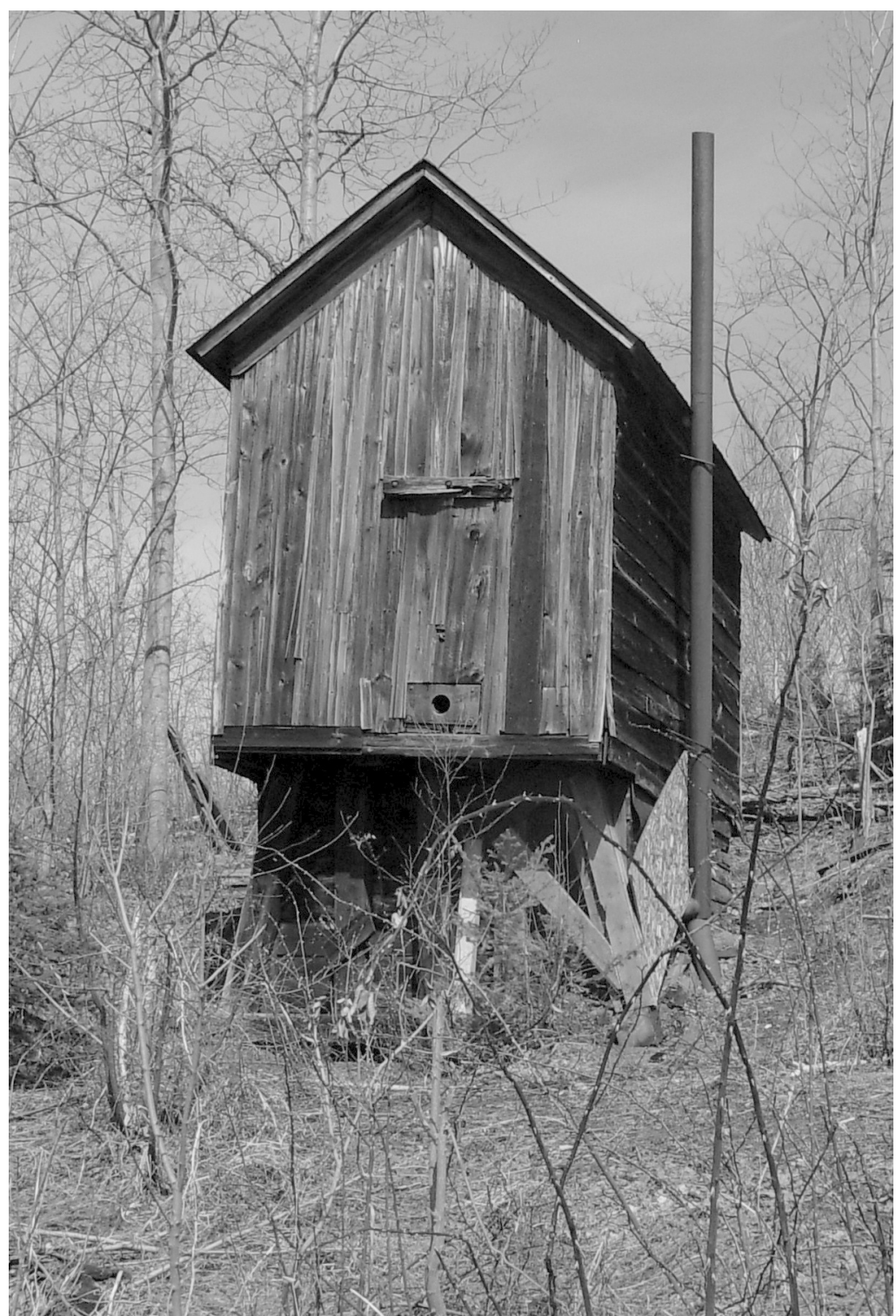

Figure 8. The Quincy \& Torch Lake Railroad water tower was used to store water for the locomotives. The flow of water into the locomotive's tender was controlled by a valve and directed by spout (missing) aimed by a trainman at an opening in the top of the tender. Photo by Dennis H. Leopold. 


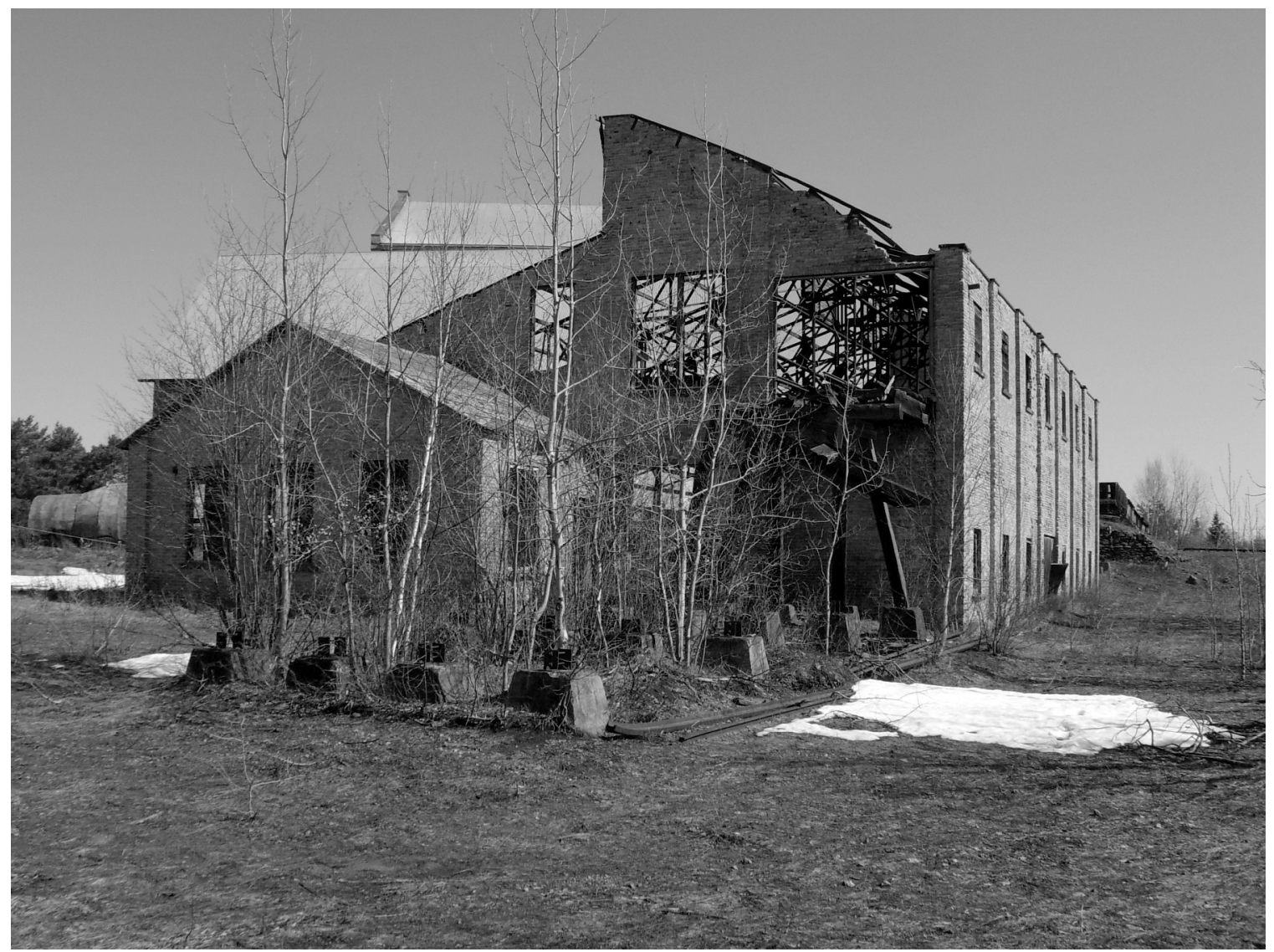

Figure 9. The Quincy \& Torch Lake Railroad coal stage was located at the Quincy No. 5 boiler house and continued to serve the mine's locomotives long after the boiler house stopped providing steam at the No. 2 facility. Photo by Dennis H. Leopold 


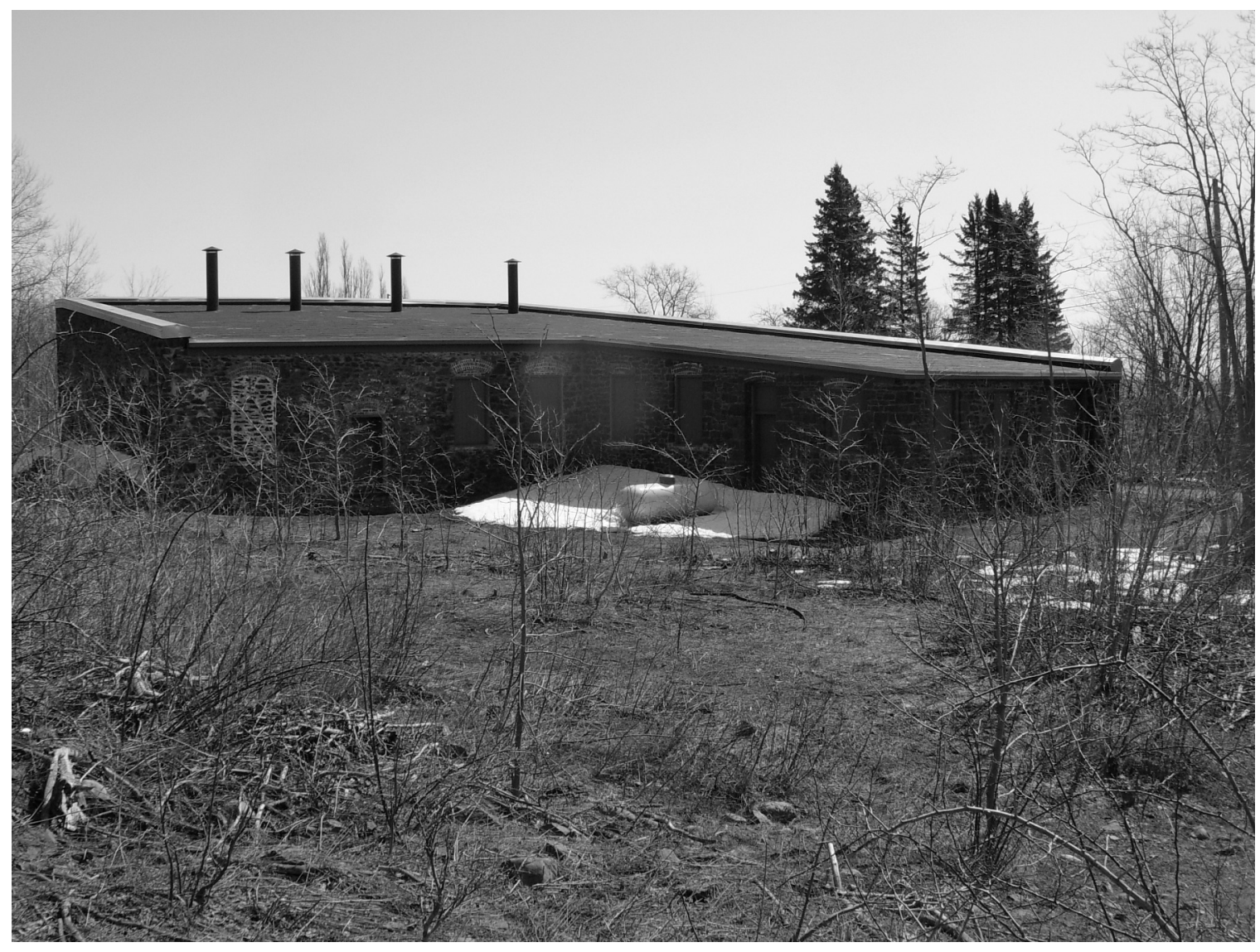

Figure 10. An April 2011 view of the west side of the Quincy \& Torch Lake Railroad engine house. The new roof and replicated, but functional, smoke jacks are clearly visible in this image. Photo by Dennis H. Leopold. 


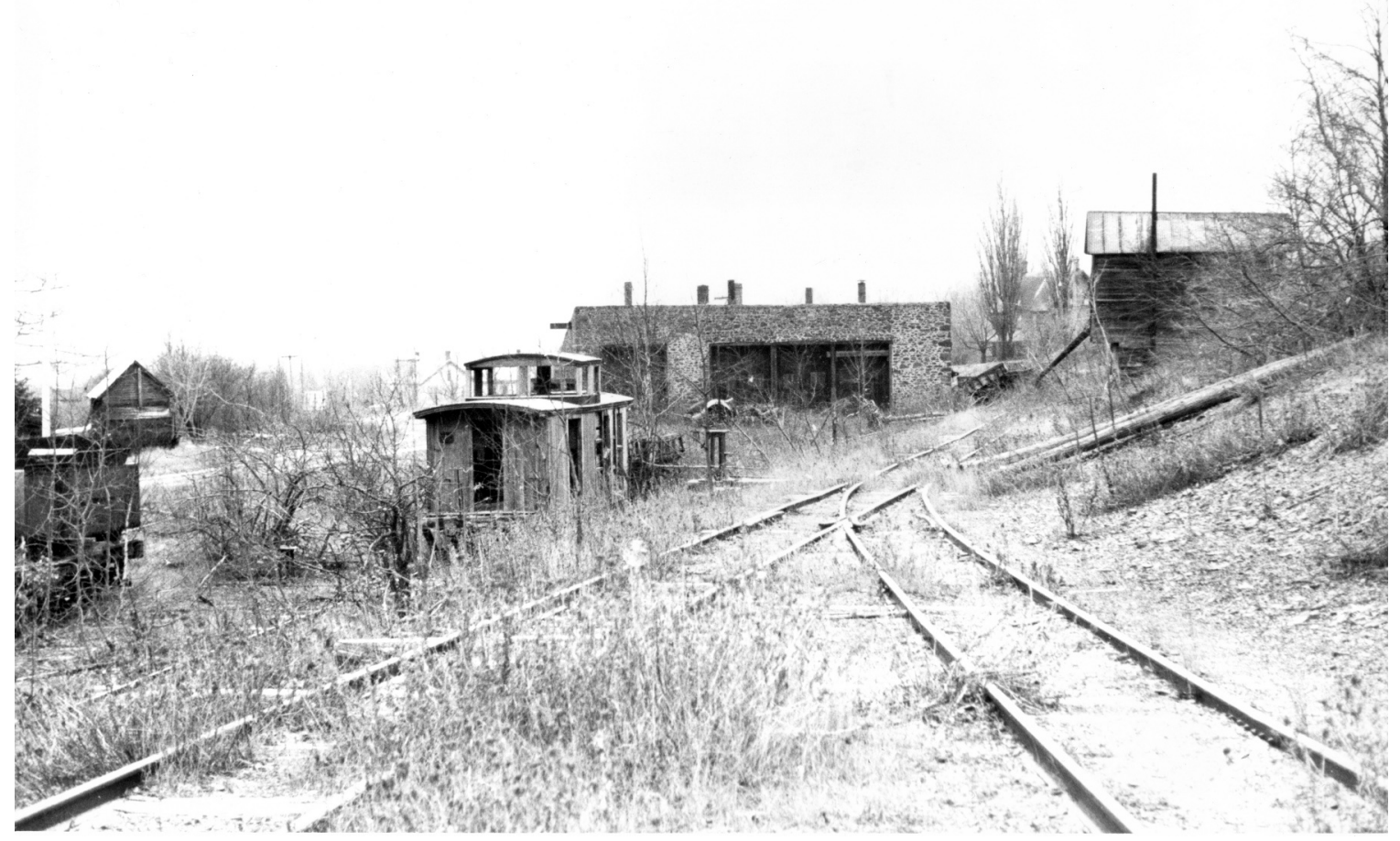

Figure 11. Frozen in time, this 1974 photo shows the engine house facility as it was the day the mine closed. Note grade elevation change between track running past the water tower and the caboose. Photo by Rudy Maki. 


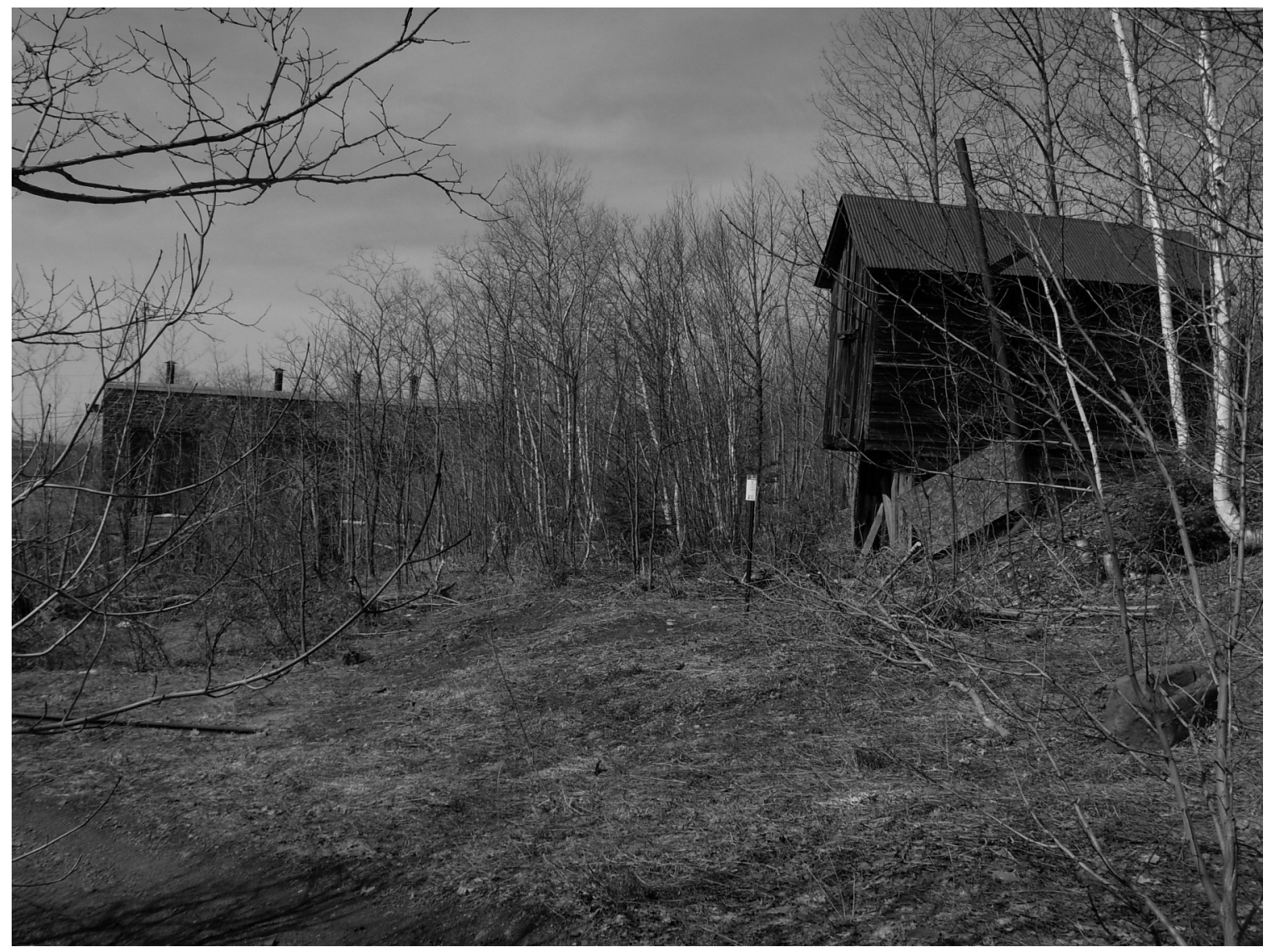

Figure 12. A view similar to Figure 11, but taken in April 2011. The engine house facility is overgrown with second and third growth vegetation and obscures the elevation changes within the engine house yard area. Photo by Dennis H. Leopold. 
The engine house is located approximately 1000 feet to the west of the main exhibit complex and is accessible by foot along the grade from the No. 5 boiler house at the No. 2 hoist building. It is also accessible from the street and is located on dead-ended Roundhouse Road, about a half mile drive from the main exhibit.

A substantial amount of vegetation at the structure and along the railroad grade blocks a direct view of the engine house and water tower both from the hoist house and highway. Vegetation also obscures the existence of the grade and yard area (Figure 12). Within the brush along the grades are various pieces of equipment, including an old tender and several rock car bodies once use for hauling poor rock away from the shafts. No rail remains in place anywhere within the Engine House Facility project area.

\section{Engine House Facility}

When the Quincy Mining Company decided to build its own railroad in 1888 it ordered and soon received the railroad's first locomotive. The Thomas F. Mason was delivered in June of 1889 , and a second followed in the fall, arriving in November (O'Connell 1978, 652). Quincy Mining Company planned and built the Quincy \& Torch Lake Railroad Engine House Facility specifically to house and service the railroad's locomotives. The facility included a 50 foot turntable, an enclosed water tower, and an open coal and sand shed to provide water, fuel, and sand for the locomotives. The engine house facility was simple, but functional, meeting the railroad's early needs.

The engine house was built of poor rock, waste from the mine (Figure 13). It had two stalls with service pits in each and was modified several times over the years to meet the railroad's increasing needs. As more locomotives were acquired by the railroad, additional stalls were added to the building (Figure 14). The fourth and final stall was completed in 1900 and was long enough to accommodate a locomotive and a rock car. The last major change occurred at the facility in 1912 when the 50 foot turntable was removed and replaced by a three-way switch at the engine house and a wye at the far end 


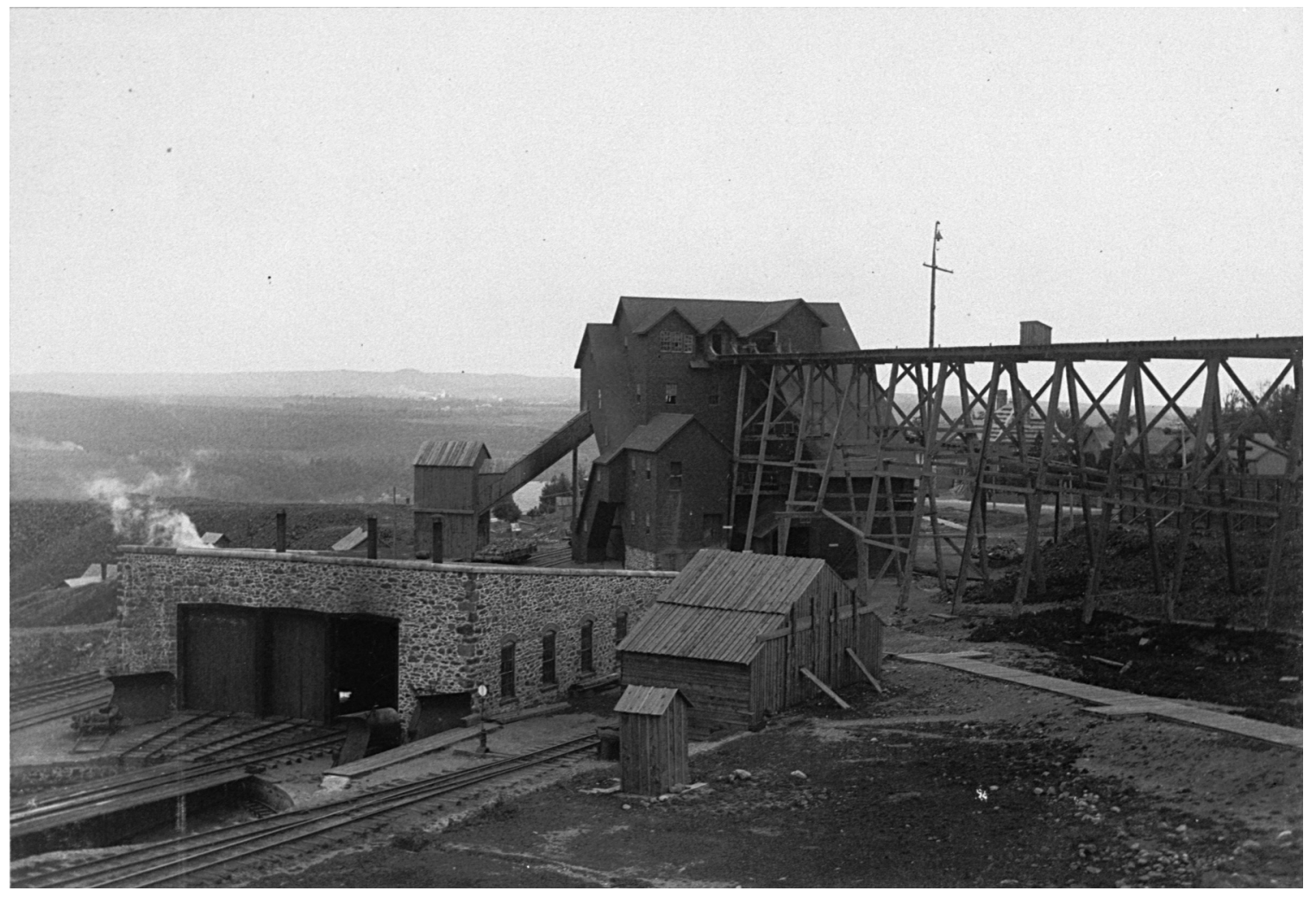

Figure 13. The Quincy \& Torch Lake Railroad engine house, circa 1897. A third stall was added in 1894. Photo courtesy of Historic American Engineering Record, HAER MI-2-72. 


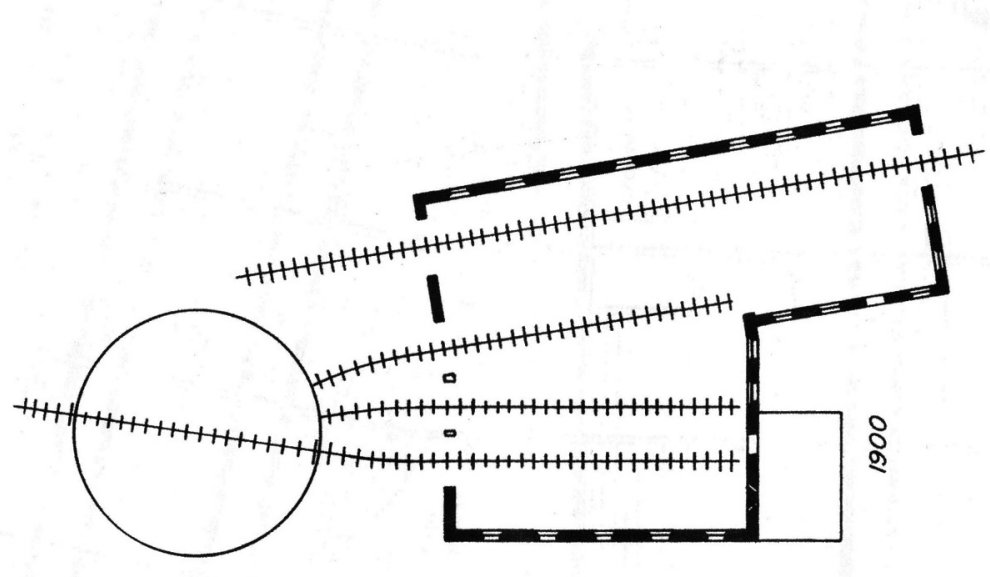

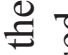

䒕?

ฮี

¿

的

음

记

ว

을

$\Xi .0$

50

व

$\triangle 0$

용

응

8

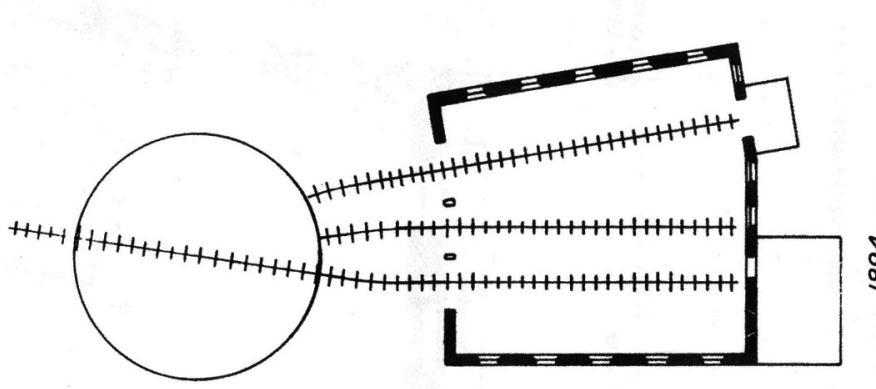

들

$\div$ 이

का के

\& $\quad 00$

8

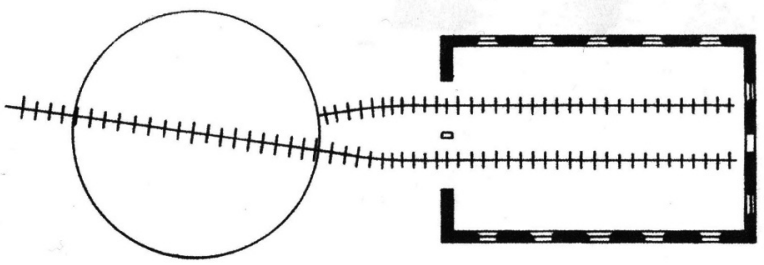

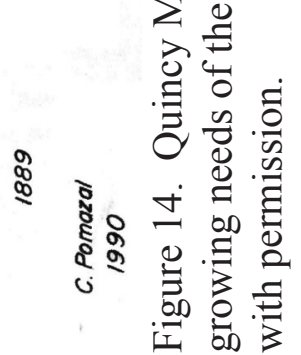


of the yard (Pomazal 1991, 25). This was done following the purchase of the railroad's sixth and final locomotive. The engine house was an important component of the railroad and had grown to be more than a storage facility used to house locomotives and now included shop space used to maintain locomotives and other equipment.

The mining company continued to expand through the end of the $19^{\text {th }}$ century and so did the railroad as it adapted to increasing demands at the mine. To accommodate the growing needs of the mine and railroad, the engine facility eventually incorporated a machine shop and blacksmith's forge to streamline maintenance activities and car repair. Larger items, such as drive wheels and steam chest castings were too large or complex for the engine house shop and were sent to the mining company's main shop. Despite some limitations, the engine house was able to do moderate work, streamlining maintenance tasks by eliminating the need to ship all work to the mine shops, slowing their work and delaying the railroad's. The engine house was fully equipped with work benches, tool and parts cubbyholes, a large variety of hand tools, and a collection of homemade and commercial machines. These were used in the daily activities of maintaining the railroad's various pieces of equipment and were needed to perform the majority of necessary tasks to keep the railroad operating smoothly and with little interruption (Wilson 2010).

The wider Engine House Facility included an enclosed wooden water tower and a coaling stage. The water tower was fully enclosed and heated to prevent the water in the tank from freezing during the winter months and served the railroad until the end of operations. Fueling practices changed little in the first decades of operation. An open shed was used to store coal for the locomotives, and workers loaded coal into the locomotive's tender using an 850-pound capacity bucket with a manually operated crane (Wilson 2010, 36). The same shed also contained locomotive sand, which when needed was directed from bulk storage on the engine and spread over the rail head to aid 
engine traction when hauling heavy loads. Later, when the Number 5 boiler house was completed at the Number 2 hoist house, the coal stage was moved to the new boiler house (Figure 15). The new coal stage fed locomotive tenders from an overhead bin filled with coal from a rail car above it. A trainman on the locomotive's tender opened a gate on the coal chute, and gravity directed coal down into the tender.

Many aspects of the railroad's operation relied on a workforce who served the railroad and the mine in varying capacities. Quincy \& Torch Lake Railroad employees were responsible for a number of tasks related and not-so-related to the daily operation of the railroad. They filled rock cars, directed rock into storage bins above the stamp heads at the mill, did track work, repaired equipment, and from time to time even worked on company owned-houses (Wilson 2010). In the first years of operation roughly ten men served the line, by 1895 the number had grown to more than forty (Wilson 2010, 36). The engine house served as the railroad's main office, and men reported there early in the morning to start their day on the railroad.

The early $20^{\text {th }}$ century saw the peak of mining at Quincy, and the railroad ran as many at twelve rock trains a day, hauling twenty rock cars down the hill from the mine to the mill. The majority of return trips included coal loads from the mining company's coal dock on Torch Lake. After the purchase of engine No. 6, the number of cars per trip between mine and mill increased due to the greater hauling capacity of the heavier locomotive. The No. 6 pulled a Q\&TLRR record of 40 plus empty cars uphill from the mill in the 1920s. The greater pulling capacity of No. 6 meant fewer trips between the mine and mill, allowing the railroad to get by with fewer locomotives. When Quincy closed the mine in 1945, the Q\&TLRR had three functioning locomotives. These were stationed in the engine house on September 1, 1945 under the assumption that they would be running again very soon. 


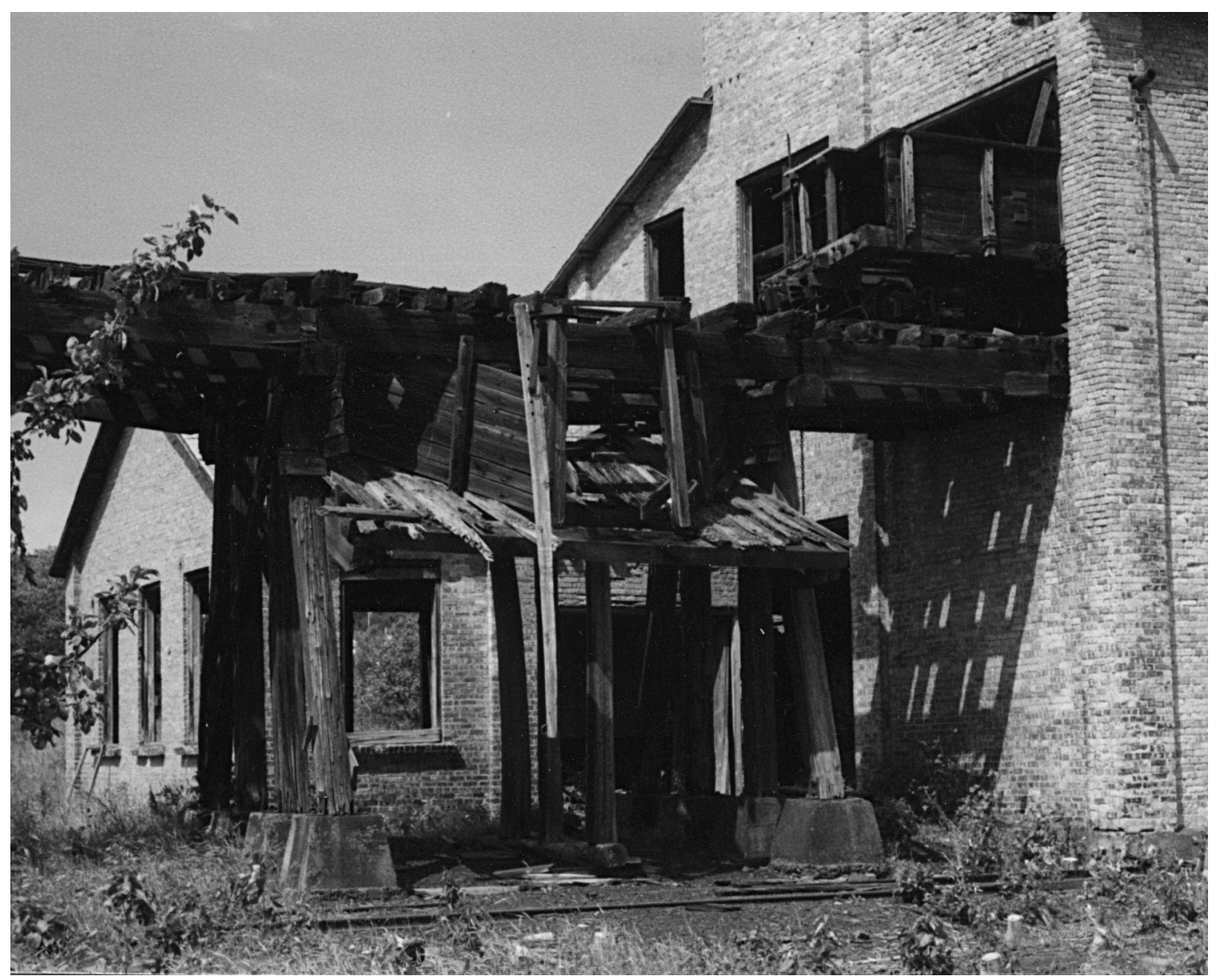

Figure 15. The locomotive coal stage at the No. 5 boiler house was a timber structure incorporated into the trestle work extending from the west wall of the boiler house. Photo courtesy of the Quincy Mine Hoist Association. 
The Quincy \& Torch Lake Engine House went undisturbed for nearly thirty years; and the locomotives sat ready with coal still in their tenders, with only an occasional visit by Quincy's watchman or a history buff (Figure 16). Then in the early 1970s Quincy Mining Company came back to life with a flurry of activity as plans to reopen began to materialize. Quincy had suspended mining operations in 1945, and at that time only the Nos. 6 and 8 shafts were in production. However by 1970 both the Nos. 6 and 8 structures were gone. If the mine were to reopen, a modern facility would have to be constructed to replace what remained of the long out-of-date equipment. In 1975 Homestake Copper Company took to the task and constructed a new head frame and hoist at the No. 8 site. Homestake and Quincy formalized the venture in 1976 (Hoagland, et al 2007, 169). Quincy committed nearly half a million dollars to the project and scrapped much of its outdated machinery at the mine, sparing only the No. 2 facility.

Quincy Mining Company completed clearing the mine site of what they considered non-essential equipment—equipment that could no longer be made safe or serviceableby 1978. That work included the Quincy \& Torch Lake Railroad with the exception of railroad equipment at or near the Hoist exhibit. Most of the rail had been pulled up in 1973 and the wood rock cars were crushed, burned and hauled off by local scrap dealers by the end of 1975 . Following on the scrap dealer's heels, employees and volunteers from the Pine Creek Railroad of the New Jersey Museum of Transportation at Allaire State Park arrived to package up and ship Q\&TLRR \#6 and the railroad's Russell Snow Plow back to New Jersey--Q\&TLRR \#6 was acquired by QMHA in 2009 and has been returned to the engine house. Part of Pine Creek's agreement with the mining company for the locomotive and plow included the extraction and placement of two remaining intact steam locomotives from the engine house to the Hoist exhibit (Figure 17). When their work was completed, the engine house was left virtually empty. The mining company had planned to raze the building, but QMHA expressed an interest in someday 


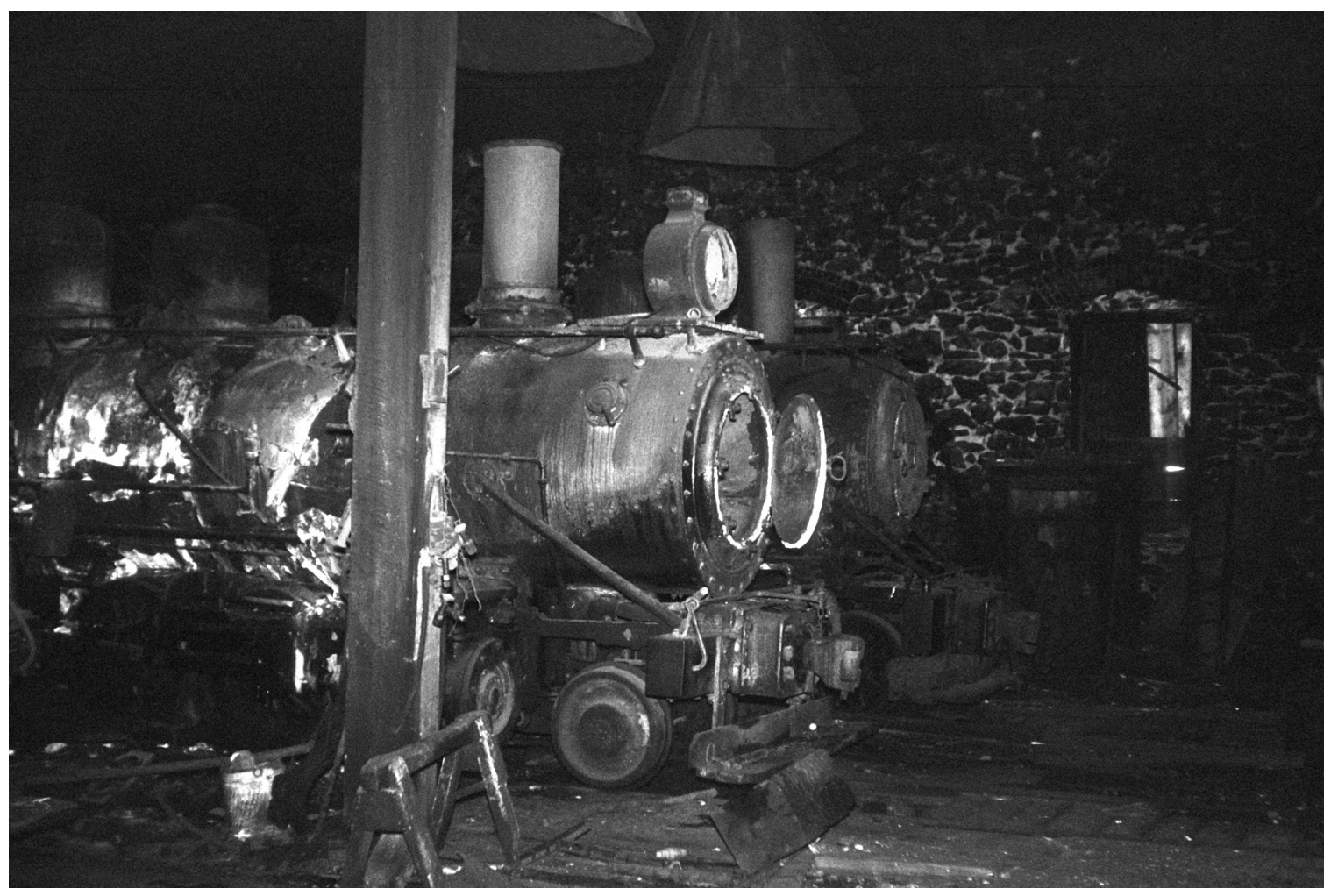

Figure 16. Quincy \& Torch Lake Railroad locomotive Numbers 5 and 1 at the engine house in the 1960s. Photo by Scott Dixson, courtesy Quincy Mine Hoist Association. 


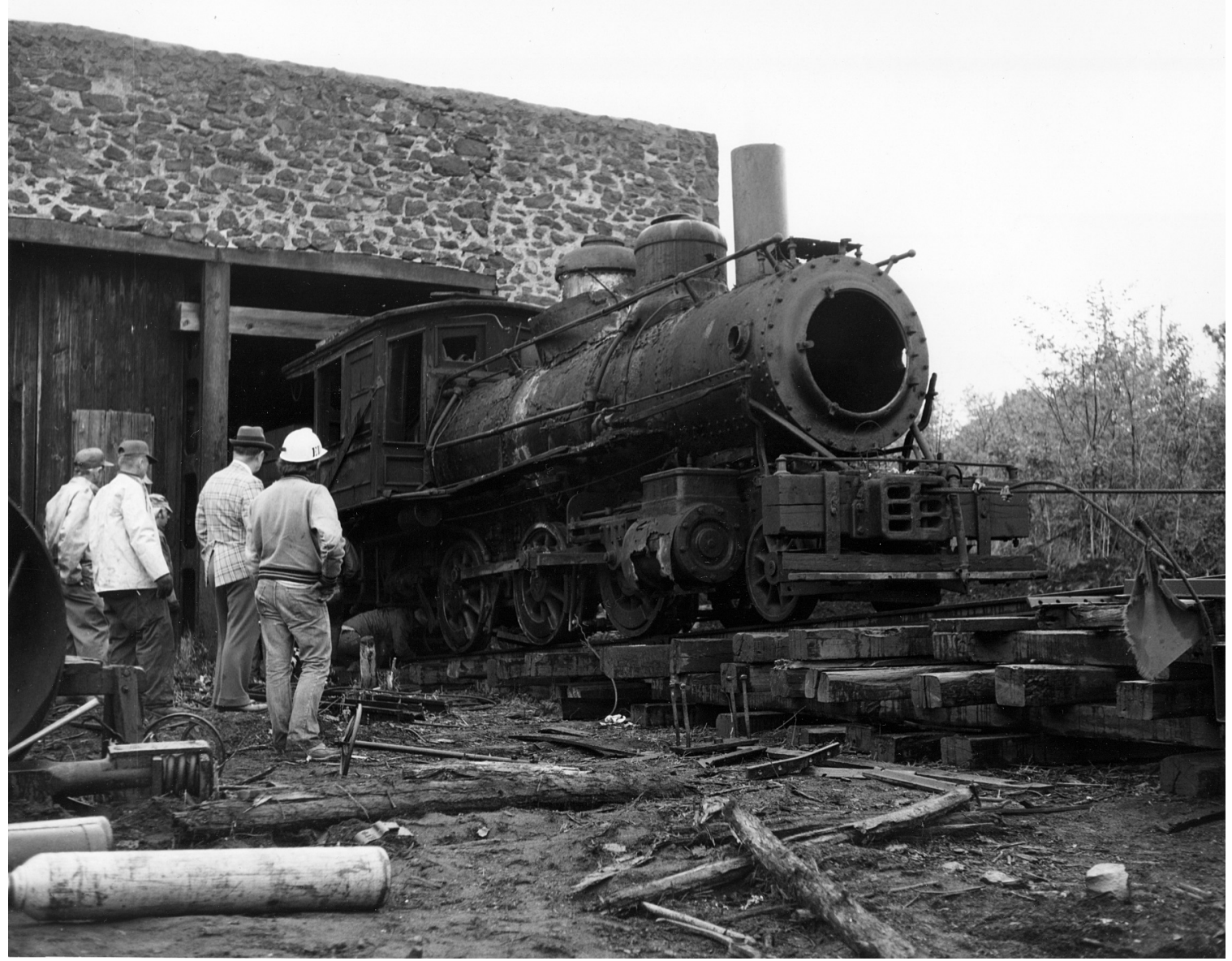

Figure 17. Members of the Pine Creek Railroad prepare to move Quincy \& Torch Lake Railroad Locomotive \#1 to the No. 2 hoist exhibit. Photo by Rudy Maki. 
restoring the structure, and the mining company relented on its plans. The engine house now stood empty, save for the dismantled hulk of engine \#3, which eventually made its way to the Huckleberry Railroad in Flint, Michigan.

\section{Current Conditions}

Time took its toll on the Engine House; by 1990 the roof had completely failed, and what remained of the equipment and tools inside were now completely exposed to the elements. What had been a relatively slow weathering over a course of 50 years began to accelerate. By 2000 the walls were beginning to show signs of failure, wooden parts bins and work benches were rotting, tools and machinery that remained were deteriorating, and the railroad's manager's office had completely collapsed. Positive action was needed if there was any hope of restoration.

QMHA's interest in restoring the engine house was rekindled in 2000 by the hoist association's manager, Edward Yarborough, and work to ensure that end began almost immediately. The structure was cleared of brush and modern trash by QMHA staff; it had become a local dump site and remnants of old furniture and such were accumulating. The water tank structure was sealed off to deter further vandalism, and in 2004 QHMA received a grant from the NPS to stabilize the structure. Remains of the roof were removed, the rock walls were capped and sealed, and the iron roof beams were shored up to prevent them from pulling the walls down as they rusted away(Figure 18). That work marked the first steps towards the ultimate goal of restoration.

In 2004 QMHA applied for additional funding to enable further restoration work. QMHA received a Transportation Enhancement Grant administrated by Michigan Department of Transportation in 2009, and work at the engine facility moved from stabilization towards restoration. Following Wilson's archaeological investigation in 2009 (Figure 19), work progressed on clearing the site in preparation for construction 


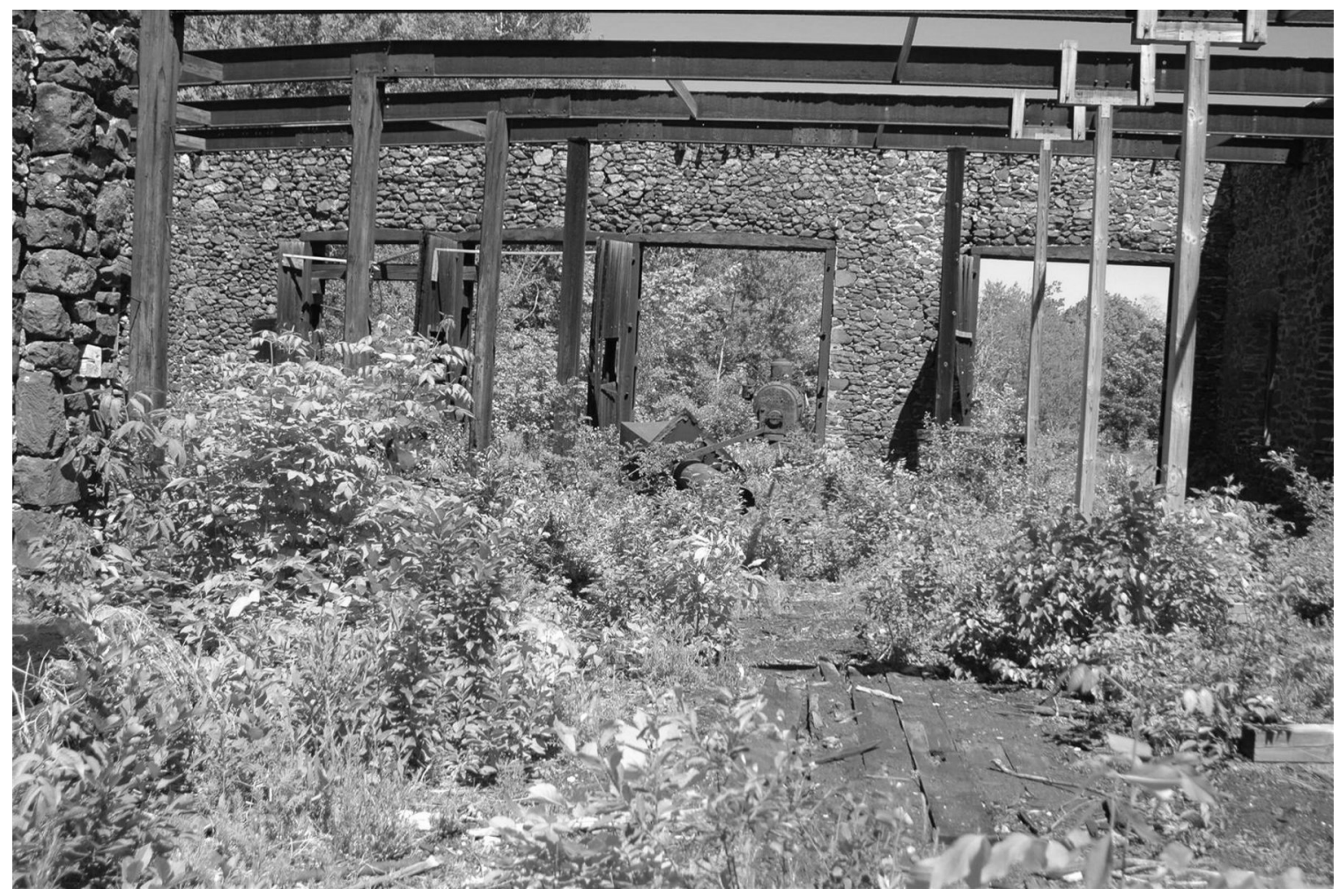

Figure 18. This picture was taken from the rear of the engine house and shows the extent of work that would be required to restore the structure. This image was taken in early summer, 2010. Photo by Mark Dice. 
PLAN VIEW

OF

EXCAVATIONS \& LARGE ARTIFACTS

Q\&TL RR ENGINE HOUSE

QUINCY MINE, HANCOCK

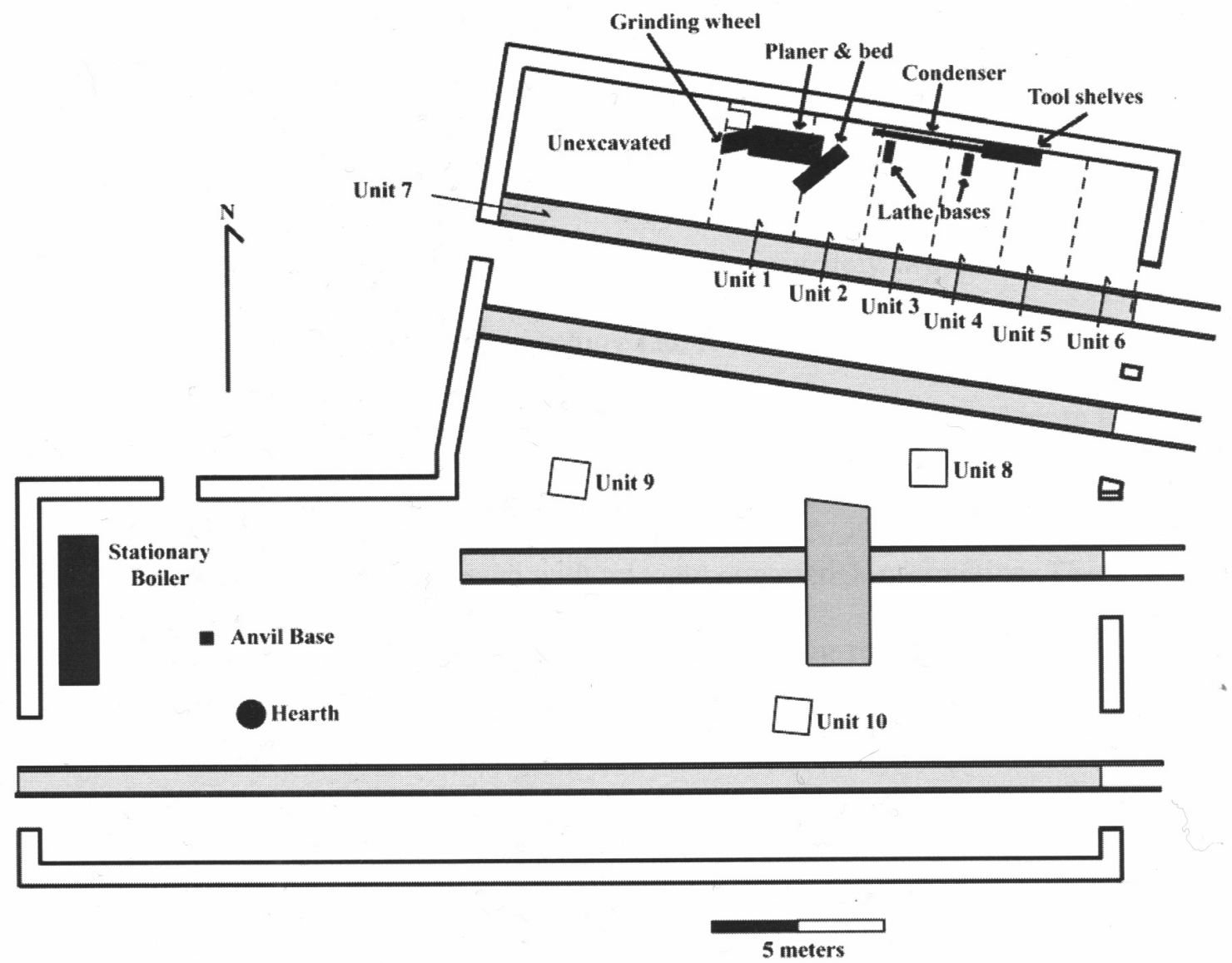

Measured and drawn by: $C$. Wilson

19 July 2009

Figure 19. Map showing the location of Wilson's 2009 excavation units within the Quincy \& Torch Lake Railroad engine house. Drawing by C. Wilson, from Wilson, "Ruin to Museum" 2010. 
crews. In the spring of 2010 LJJ Contracting began rehabilitation work on the structure. The engine house was emptied of large and small artifacts; items collected were stored on pallets which were returned to the structure in the fall along with large machines. The metal beams that supported the roof were replaced, and rock work was tuck-pointed, and crumbling walls repaired. All windows and door frames were repaired using as much original material as possible. New doors were made and installed, two engine pits were stabilized and restored, and remaining pits were cleaned out and filled with gravel. A new roof was constructed, and new smoke jacks replicating originals were installed. At the same time several members of the contractor's team also worked to stabilize the Quincy \& Torch Lake Railroad water tower. The final step completing phase one reconstruction work occurred in late fall when gravel was spread over Visqueen covering the original engine house floor surface. The structure was now fully enclosed and was ready for phase two restoration work. Planning for the next phase is in part the purpose for this document. 


\section{Management Plan}

The engine house has been stabilized and plans for the second phase restoration work are moving forward. It is critical that this document be used to direct future planning and development at the site. This plan will assist in protecting the engine house and other valuable historic resources, such as equipment and landscape features, by guiding further development and interpretive planning at the Engine House Facility. Significance and mission statements establish the value of the exhibit and focuses the desired outcome, upon which the success of the project can be measured. The desired outcome is directed by goals and objectives, and considerations and influences. These establish a base to build further restoration work, site development, and help to direct interpretive programming by aiding the design process and the creation of interpretive themes.

Periodic review and evaluation of the plan over the course of the restoration process and interpretive program development will help management evaluate the success of the project by comparing ongoing and future activities with actual activities and planned actions (Components 2007, 3 and 4).

\section{$\underline{\text { Statements of Significance }}$}

The significance statements outline the importance and distinctiveness of the site that is the focus of study or of preservation, touching on its tangible and intangible characteristics (Planning 1998). These statements convey the importance of the Engine House Facility and can highlight activities that took place there, the people involved, and how the site fits in with the wider area. Significance statements when taken as a whole will point out the historic, cultural, scientific, recreational, and inspirational value of the site and include the tangible and intangible aspects of the site (Kohen and Sikoryak 2005). The following are a set of Significance Statements for Quincy Mining Company's Quincy \& Torch Lake Railroad Engine House Facility: 
- The Quincy \& Torch Lake Railroad Engine House Facility is included within the boundaries of the Quincy Mining Company National Historic Landmark, recognized by the National Park Service as having a high level of historical significance in the Service's system.

- The Engine House Facility is the link that tied together all major components of copper production, from mining to processing and transportation to market.

- The engine house was the hub of Quincy rail operations. Quincy employees who worked on the railroad reported to the Engine House at the start of each work day. All trains and maintenance tasks on the railroad were dispatched from the engine house.

- The Quincy Mine's locomotive Engine House Facility includes the original engine house, water tower, coal stage, and yard right-of-way. It is the only intact engine facility in Michigan's copper district, and is one of the better preserved steam-era railroad facilities in Michigan.

- Extant rock cars, locomotives, railroad grades, and structures make this facility a significant resource in the Copper Country.

- The Engine House Facility provides an opportunity to explore work environments and labor beyond the mine and demonstrates the diversity of the labor found at Michigan copper mines.

\section{$\underline{\text { Mission Statement }}$}

A mission statement guides discussion for current and future projects and keeps current management and interpretive planning on track (Components 2007). The mission of the Engine House restoration and interpretation project is to preserve and interpret the history, landscape, buildings, and employee work experience associated with Quincy Mining Company's Quincy \& Torch Lake Railroad Engine House Facility. This project will provide the visiting public with an opportunity to learn about and experience a vital transportation component of Michigan's copper mining industry. 


\section{$\underline{\text { Considerations and Influences }}$}

Work at the facility must comply with the Secretary of the Interior's standards for the rehabilitation of historic structures (Illustrated Guidelines 2011). In addition the following points should be considered when planning projects and interpretive programming for the engine house facility—some may prove to be difficult site management issues while others may provide opportunities for development and to build relationships within the community.

They are:

- There should be an established plan for tours at the site and a decision should be made as to who will conduct those tours; QMHA staff or KNHP Quincy Unit Rangers.

- Visitors should be directed to the site after schedule-dependent tours are completed.

- The distance between the main visitor center and the Engine House Facility should be considered when planning tours for the engine house facility; access and site accessibility at the facility needs to be considered and addressed.

- The Quincy Unit Cultural Landscape Report (2010) produced by Keweenaw National Historical Park and Wilson's report on the Engine House Facility (2010) recommend the management of vegetation at the site; clearing vegetation will create/restore a line of sight from the main visitor center to the Engine House Facility, greatly increasing visibility.

- Consideration for the residents near the engine facility is necessary as the site is located near a developing residential area. This may be an opportunity for community policing of the site.

- Some contributing components are missing or heavily deteriorated. For example railroad grades and retaining walls in some areas have collapsed.

- The yard space in front of the engine house has been encroached upon by a modern road, altering the historic yard right-of-way. This limits development or restoration of 
the full yard at Engine House Facility.

- Artifacts and features associated with the engine house are heavily deteriorated.

- An artifact storage and conservation/preservation plan needs to be developed.

- Ongoing problems with relic/souvenir collectors and scrap hunters requires action to secure the site against theft and vandalism.

- The engine facility site is actively used outside of QMHA tours. Dog walkers, hikers, and bikers, and curious members of the community explore the area and use the railroad grades as trails.

- Off Road Vehicle and automotive use of the railroad grade adjacent to the engine facility presents some risk to visitors and community members who walk the grades. ORVs are also eroding the grades and retaining walls. It is recomended that ORV use of the grade is blocked between the No. 2 hoist exhibit and the engine house exhibit.

- The Q\&TLRR Engine House Facility presents an opportunity to build heritage site networking and sharing/exchanging resources with other heritage railroad interests in the region. Consider incorporating ongoing restoration work into interpretive programs.

- The movement of people and incorporation into existing tours should be considered in the wider interpretive program development.

- Create thought provoking interpretive programming. Create engaging experience opportunities.

- Only limited interpretation is currently in place, leaving an opportunity to expand and develop interpretive and educational programs.

- Consider who will maintain interpretive displays. How will that work be accomplished?

- Exhibit space should be considered when planning locomotive and rolling stock displays. These items will fill the structure and may visually overwhelm the interior of the building. 


\section{$\underline{\text { Resource Inventory }}$}

The Quincy \& Torch Lake Railroad Engine House Management and Interpretive Plan is directed at the preservation and interpretation of the engine house facility. An inventory of available resources related to the engine house facility is crucial for future management and interpretive planning. This resource inventory includes railroad, informational, interpretive, and community resources. Railroad-related features include those located inside and outside of the project area, but wholly within the Quincy Unit of Keweenaw National Historical Park. This list should be periodically reviewed and updated to aid in future preservation, interpretive, and management efforts.

\section{Engine Facility}

- The Q\&TLRR engine facility consists of the locomotive engine house, water tower, and coal stage. A simple stone two stall engine house and 50' turntable were built in 1889; the water tower followed several years later. The engine house was constructed of local building material gleaned from the mine's waste rock piles. The structure underwent considerable modification through the first decade of the railroad's operation, adapting to meet the increased demands of a rapidly growing mining company; additional stalls were added as the mining company purchased more locomotives. The last major modification occurred in 1912 with the removal of the turntable and the installation of turning wyes at each end of the mainline. The structure changed little from that time until the company closed the mine and suspended rail service in 1945.

- The engine facility served as shop space where locomotives and cars were repaired. The facility had a machine shop and blacksmith's forge, which enabled Q\&TLRR employees to perform most repairs there, but larger repairs were made at the mine's regular shops located about a half mile away. Crews reported to the engine house at the beginning of each shift, and all trains bound for the mill and maintenance work along 
the tracks were dispatched from this facility. The railroad's superintendent also worked from this facility.

- The engine house is actively being restored. In 2010 new doors, roof, smoke jacks, window coverings, and service pit had been reconstructed/restored and installed.

- The Q\&TLRR water tower's superstructure is timber framed and was covered with clapboard siding. Originally only the steel water tank was enclosed, but due to harsh winters the structure foundation structure was enclosed and a small coal stove was installed to warm the tank and prevent freezing. This structure has been stabilized (2010), and restoration is planned for a later date.

- The coal stage, or coaling facility, was built in 1912 and is located at the No. 5 boiler house near what is now the main Hoist exhibit. Coal was burned in the boiler house to generate steam to power the No. 2 hoist. Locomotives on the Q\&TL also burned coal to generate steam. The locomotive coaling facility was integrated into the trestle work extending from the west side of the boiler house. Loaded coal cars were placed over a specially constructed bin to be emptied as needed through a gated chute which directed coal into the locomotive's tender. The coal stage structure is timber and is in ruins. Much of it was removed in 2004 to prevent damage to the adjacent boiler house structure. No immediate plans exist to restore the coal stage.

- Significant ancillary structures associated with the engine house facility, but no longer extant, include the superintendent's office, locomotive's sand shed, and engine house privy.

- In addition to structures, several landscape features, such as railroad grades and rock retaining walls, are associated with the engine house facility. Portions of the rail yard are currently overgrown in but are clearly defined by extant ties and built up rail grades.

- Dual gauge track also extended from the Mineral Range and later Duluth, South Shore \& Atlantic Railroad mainline to the engine house facility. 


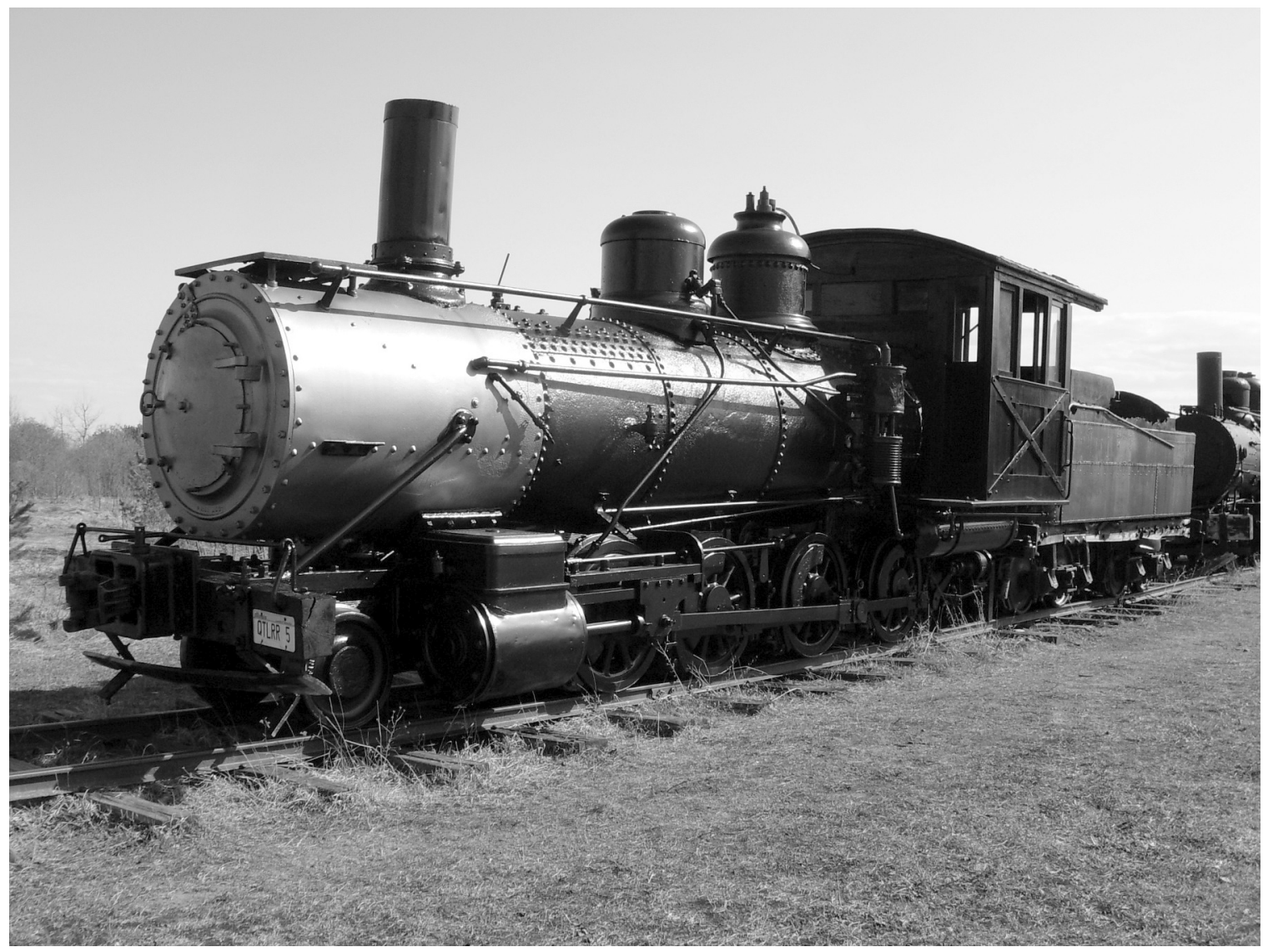

Figure 20. Quincy \& Torch Lake Railroad \#5 is displayed at the No. 2 hoist exhibit and is currently being cosmetically rehabilitated. The locomotive was purchased by the Quincy Mining Company from the Hancock \& Calumet Railroad and is one of only a few surviving locomotives in the region representing other steam-era railroads. Photo by Dennis H. Leopold. 


\section{Extant Equipment}

- Steam locomotives are the most recognizable feature of a steam-era railroad. Three are presently owned by QMHA. Long term plans call for all three QMHA-owned locomotives to be moved to and stored at the Engine House.

- Q\&TL No. 1 was constructed in 1889 and was the first locomotive on the property; it was also the last engine to operate on the railroad, 9-1-1945. This locomotive is displayed near the No. 2 hoist exhibit.

- Q\&TL No. 5 was purchased from the Hancock \& Calumet RR and is currently being restored for static display and is near the hoist exhibit. It has the dubious honor of being involved in the only fatal locomotive accident on the Q\&TL (Figure 20).

- Q\&TL No. 6 was purchased in 1912 and was the largest narrow gauge steam locomotive to operate in the Copper Country (Figure 21). The locomotive was acquired by QMHA in 2009 and is stored at the engine house.

- Quincy Mining Company owned in excess of 140 rock cars. The majority of them were drop bottom gondolas of varying styles. The drop bottom gondolas were used to transport ore from the mine to the mills and haul coal up from the coal dock to the mine. Twenty-eight cars still exist in varying states of ruin on the property (Figure 22). These cars were acquired new from the manufacturer and used from several local narrow gauge railroads. Surviving cars represent a sample of all rock car styles used by Quincy Mining Company on the Q\&TL.

\section{Miscellaneous Features}

- A number of rail related features exist outside of the study area. The most significant are the railroad grades that weave their way through the landscape, still connecting major components of the Quincy industrial complex. Rock fills and retaining walls at or near a number of shaft and boiler house sites are still extant, marking the former 


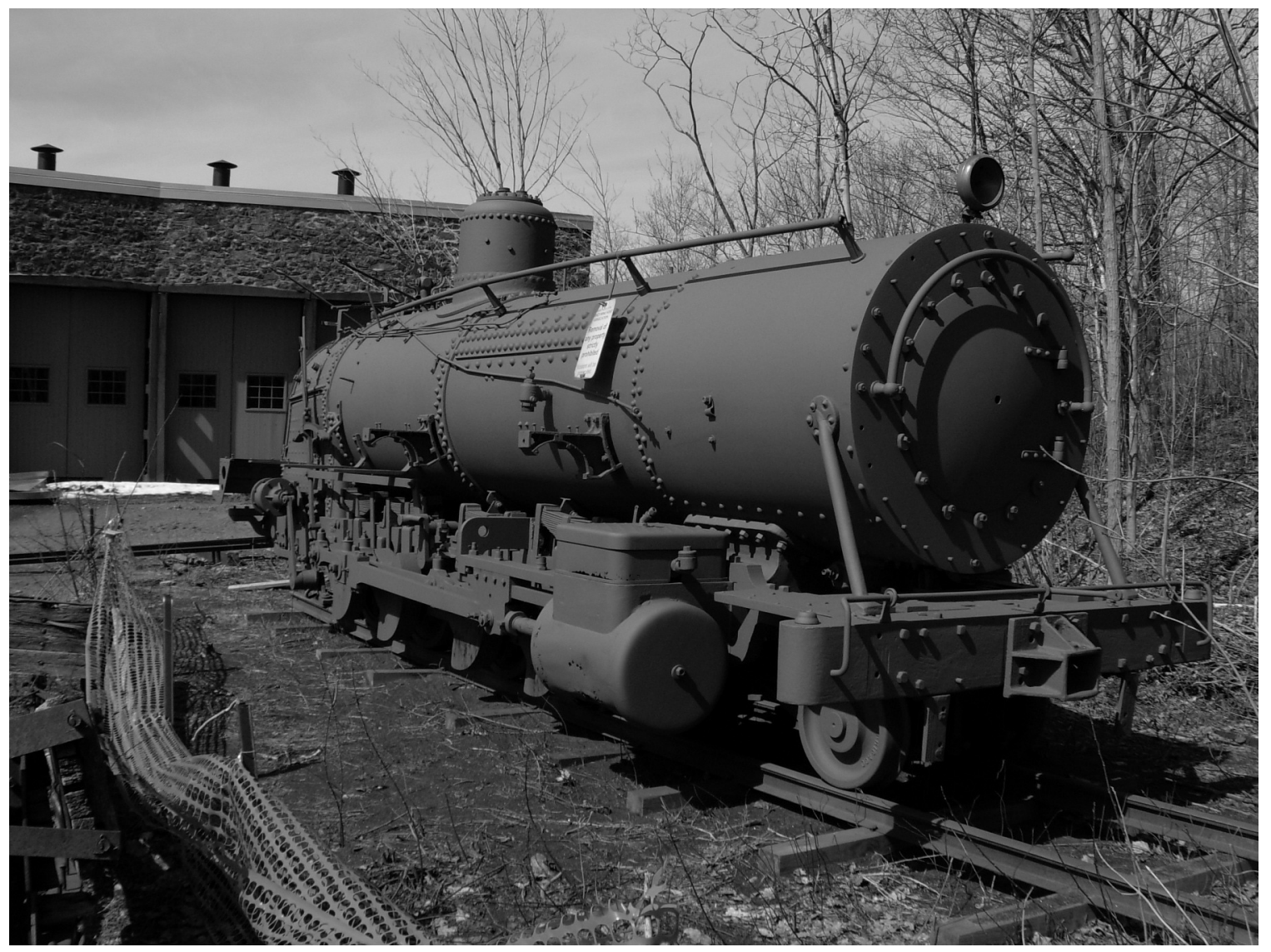

Figure 21. Quincy \& Torch Lake Railroad locomotive \# 6 returned from New Jersey in 2009. In this April, 2009 photo, No. 6 is in the early stages of stabilization work. It is being prepared for display at the engine house. Photo by Dennis H. Leopold 


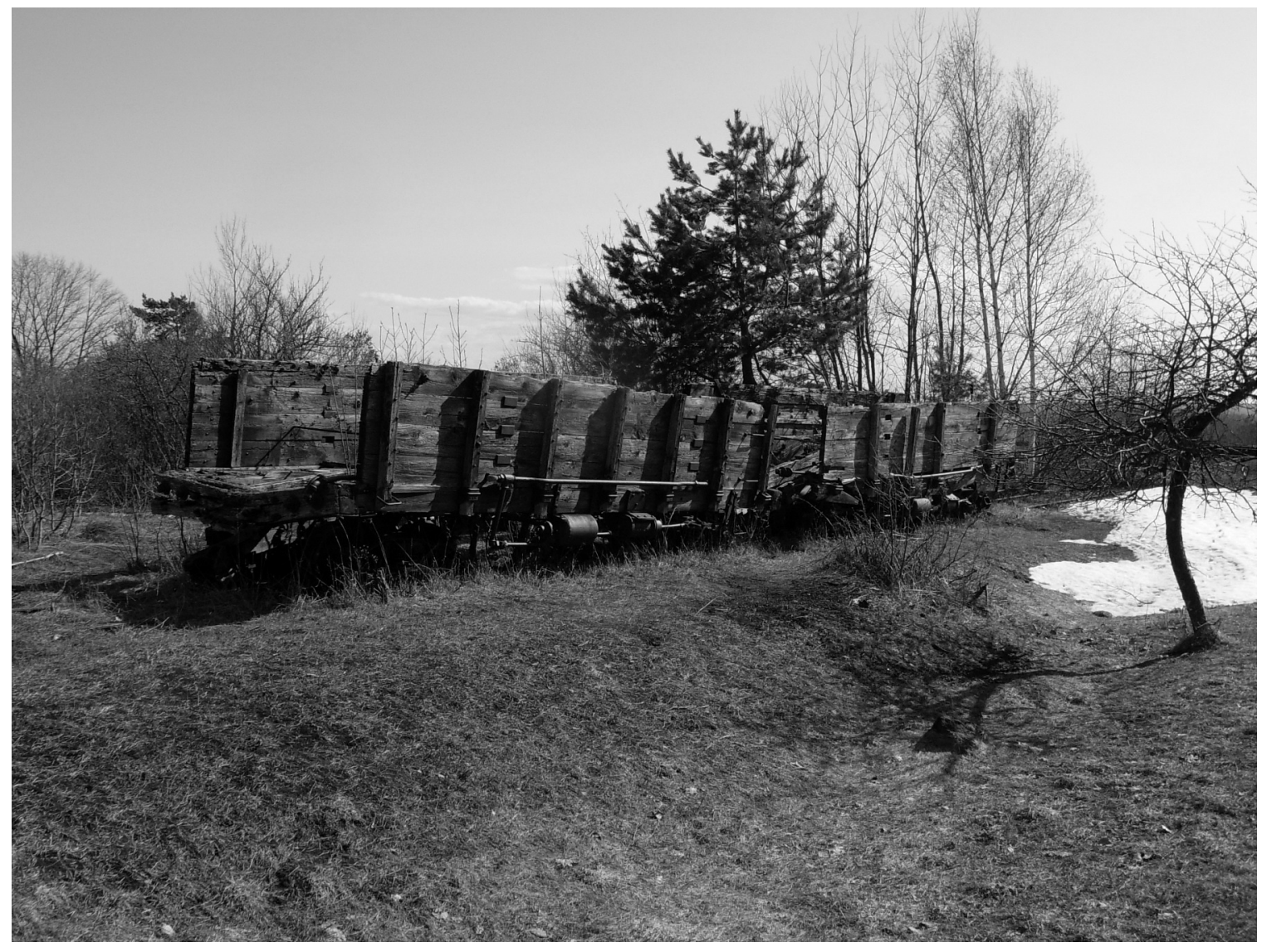

Figure 22. Two wooden rock cars used to haul copper rock from the mine to the mill on Torch Lake, and coal to fuel the boilers at the mine from the company's coal dock located near the mill. Photo by Dennis H. Leopold. 
locations of coal docks and tail tracks at the No. 2 Shafthouse. These features contribute to the overall appeal of the industrial landscape.

- Long ago, old wooden trestles spanning several major, deep gullies along the mainline were filled in with poor rock. These rock fills attest to the large volumes of waste produced by the mining company and illustrate where much of the waste rock was deposited.

- The engine house was cleared in preparation for restoration work. Many artifacts, such as hand and machine tools, various car and locomotive fittings, air and steam lines, a stationary boiler, and blacksmith's forge were collected and removed. They are currently stored in the engine house.

\section{Informational Resources}

- Michigan Technological University Archives and Copper Country Collections and Keweenaw National Historical Park both house collections of Quincy Mining Company corporate records, including several collections donated privately. Both host a wealth of additional information.

- Houghton County Historical Society Library and Archival Collections maintains a collection of files related to Copper Country mines.

- HABS/HAER 1978 Record of Quincy Mining Company, Library of Congress. This document is available at the Library of Congress's web site and in the archives at Michigan Technological University.

- Keweenaw National Historical Park has produced some publications for and including the Quincy Unit. For example, the Quincy Unit Cultural Landscape Report, and Keweenaw National Historical Park General Management Plan.

- Michigan Technological University Industrial Archaeology Master's Program have produced some Quincy specific documents and includes Heather Spencer's Interpretive Trail project and Craig Wilson's Thesis and report on archaeological findings at the 
Engine House..

- There are also a number of publications on local history that include discussions or brief histories of the Quincy Mining Company. For example, "Old Reliable," "Cradle to Grave," and "Beyond the Boundaries" by Larry Lankton.

\section{Management/Interpretive Resources}

- Currently NPS Rangers, QMHA staff and volunteers conduct guided tours throughout the Quincy No. 2 Shaft and Hoist House exhibit. NPS Quincy Unit Ranges currently conduct thirty minute walking tours of the exhibit area. The Engine House Facility will contribute to those tours by allowing them to address the significance of transportation in copper production.

\section{Community Resources}

- A call to the public may generate offers for oral histories, photographs, company records, etc. For example several members of the Quincy Hill community have been lifelong residents of the area and tell stories of hooking rides on the rock trains as kids.

\section{Engine House Goals and Objectives}

Goals and Objectives express the desired outcome of actions and guides those actions to acquire a desired effect. At its core the desired outcome of ongoing work at the Quincy \& Torch Lake Railroad Engine House Facility is the creation of additional exhibit space and interpretive programming which will be used to communicate the significance of transportation systems in Michigan's Copper District.

The objectives outlined below provide a base that can be modified or added to as deemed necessary, upon which progress at the engine facility can be easily measured and the ultimate success of the project can be judged.

\section{Goals and Objectives}

Goal 1. Preserve industrial heritage resources related to and found at the Quincy \& Torch Lake Railroad engine house facility. 
Objectives:

- Identify and address immediate needs.

- Secure site against theft.

- Restore engine house and water tank.

- Retain in restoration projects as much original fabric as possible.

- Provide proper storage and care for artifacts.

- Relay rail in engine house.

- Clear vegetation and expose railroad grades.

- Provide interior environmental controls, secure against fire.

- Return locomotives to engine house for conservation and rehabilitation.

- Restore rock retaining walls along grade near engine house.

- Restore coal stage at No. 5 boiler house.

- Reconstruct missing buildings such as sand shed, outhouse.

- Restore yard track up to modern tram road

Goal 2. To educate the visiting public about the railroad, its employees and the role that railroads played in mining and in the Copper Country as a whole through educational programming, restoration, and interpretation.

Objectives:

- Establish an interpretive framework.

- Contextualize engine facility and yard within the mine environment.

- Present stories on individuals, workforce.

- Illustrate basic railroad technologies.

- Demonstrate Quincy Mining Company’s history (both prosperity and decline) through the railroad at the engine house.

- Use restoration projects on locomotives and rock cars to demonstrate historic use of facility. 
- Develop educational programming for example around chemistry and physics, and illustrate through railroad technology.

- Use operating equipment to demonstrate appropriate skills, i.e. blacksmithing. Goal 3. Develop a public relations program to build awareness using the engine house facility to draw and increase visitor traffic.

Objectives:

- Link into the existing heritage site network to promote and develop engine house restoration projects.

- Promote the projects within community, demonstrate significance of having only remaining steam railroad facility in the Copper Country.

- Use restoration of the engine house and related equipment as an attraction to garner interest outside of the community, reach out to industrial/rail enthusiasts.

\section{Development Stages}

The second phase of the Engine House Facility restoration project is presented here in three development stages, and are developed from the established goals and objectives discussed above. The following stages should guide the implementation of management and interpretation recommendations presented by Wilson. This section includes additional recommendations to those presented by Wilson for the Q\&TLRR Engine House Facility and organizes those recommendations into the three stages. Each stage, upon completion, is the foundation for the next, but is an end in and of itself or viewed as a step toward full restoration to be completed as funds are available. For example, implementing Stage 3, the preferred alternative, would imply that Stages 1 and 2 have been finished or will be completed concurrently with Stage 3. Alternatively, for example, Stage 2 cannot be considered complete without having also completed Stage 1.

Regardless of time frame allowed to accomplish Stage 3 and if no further action is planned for the immediate future, Stage 1 should be completed as soon as possible. 


\section{Engine House Facility}

Per Wilson's recommendations, large artifacts will not be returned to their original locations until appropriate during Phase Two of the engine house restoration project. Phase Two planning should be guided by the Quincy \& Torch Lake Railroad Engine Facility Management and Interpretive Plan.

\section{$\underline{\text { Current Status }}$}

The engine house and water tower have been stabilized. The engine house is fully enclosed, but has not been secured against trespass and theft. Artifacts associated with the engine house are currently stored inside the structure, off the ground, but they require further treatment. Also, future plans indicate that rails may be reinstalled in each locomotive bay, there are currently rails in place at the \#3 stall, but they need to be secured. Special plates are required to secure the rail to the ties and need to be manufactured before the rail can be secured at the \#3 stall.

It is recommended that the following work take place at the facility. The following stages of development are components of the next phase of restoration work at the engine house. Stage 1 should be completed as soon as possible.

\section{Development Stage 1}

Development Stage 1 work will include identifying and addressing immediate needs at the engine house. For example, construction debris litters the site and should be cleaned up before a path to the site is opened to visitors. The engine house and water tower should be secured against further decay; pooling water is a problem in the engine pits and a large hole in the east wall of the water tower should be properly repaired. Efforts should be made to retain as much original fabric as possible. It is recommended that the structure be secured against trespass and that artifacts are secured against theft, which can be accomplished by installing historically appropriate latches and locks on all engine house doors. It is also recommended that planning for interpretation at the facility moves 
forward; many options are available ranging from simple panels to audio programing. Begin exploring how to link the developing engine house exhibit into the existing KNHP heritage site network to promote the restoration project.

\section{Development 2}

The engine house needs to be made ready to recieve several large artifacts which are currently being restored on the property, i.e. two locomotives and a poor rock car. Clear most vegetation and expose the railroad grades. The use of current restoration projects at the engine house and on related equipment can be used to garner interest from the community at large. As work progresses, the restoration projects can be used to demonstrate historic activities at the facility. Work stations such as the blacksmith's forge can be reconstructed and used in locomotive and car repair work. It is recommended that the wooden floor, work benches, and tool cubbyholes be recreated before equipment is moved to the engine house for permanent display. Restoration work on extant machinery, stationary boiler; and belting system should be planned to take place concurrently with other projects. (Figure 23)

\section{Development Stage 3}

The restoration process may be accomplished in a period of time that may exceed 10 years. It is recommended that a maintenance program be designed to ensure longterm upkeep of the facility. As funding permits the coal stage at the No. 5 boiler house should be restored as well as trestle work leading into the structure from the east side. Rock retaining walls along grade near engine house should be restored. Several rock/coal cars outside the No. 5 boiler house should also be restored and returned to the boiler house for display. After restoration work on the engine house is more or less complete other appropriate railroad-related artifacts should be move to the engine house facility, for example two locomotive bells, builder's plates, and number plates can be returned to their respective locomotives for appropriate display. Missing structures can be reconstructed 


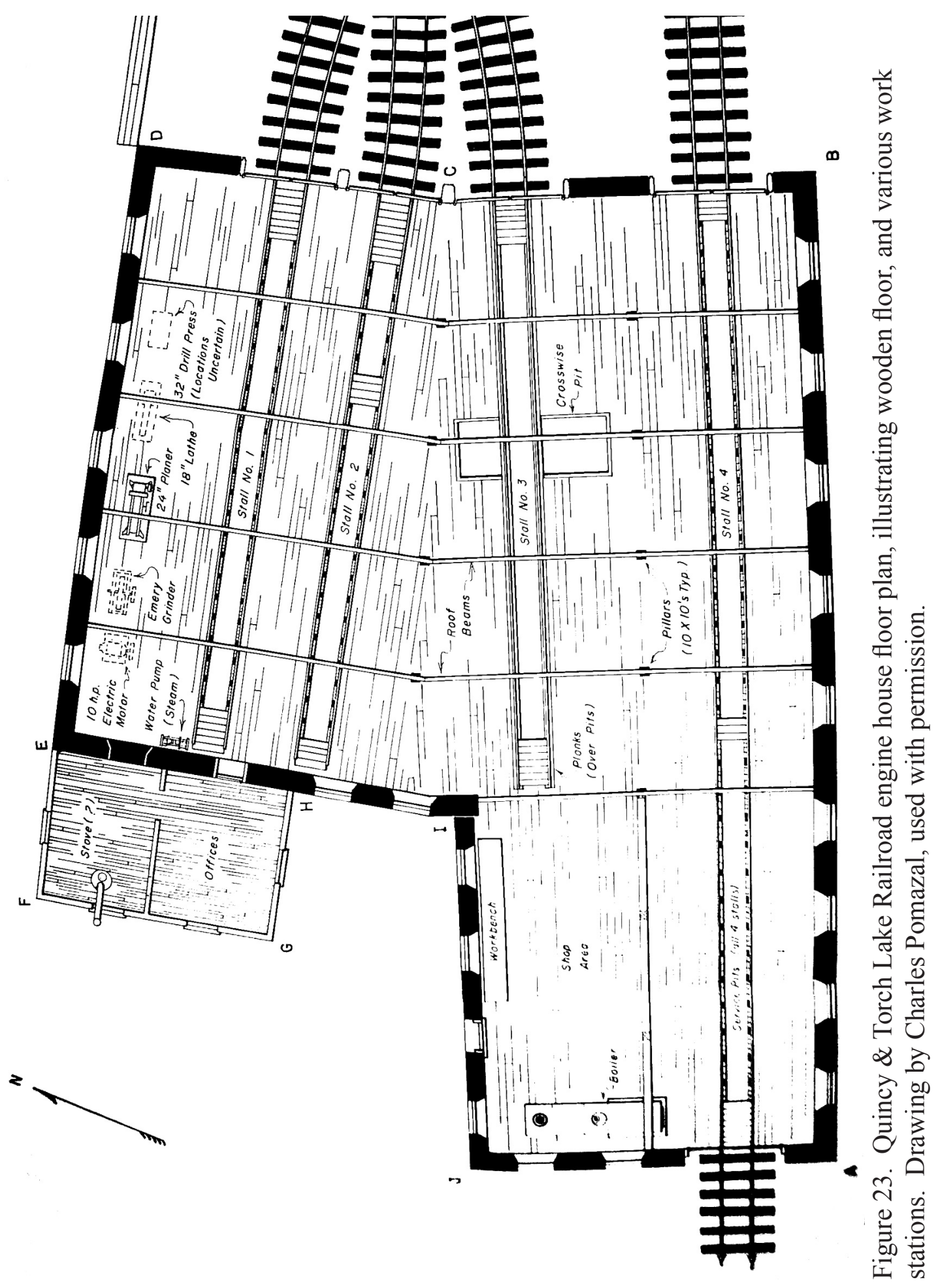


and a maintenance-of-way hand car currently stored in the No. 2 shaft house should be moved back to the facility. Long term educational programming should be developed for the site and operating equipment can be used to demonstrate appropriate work environment skills, such as blacksmithing.

The restoration process of the engine house facility may take years to complete, but planning and remaining focused on long term goals will assist in seeing the project through to completion. 


\section{Interpretive Plan}

The "Quincy \& Torch Lake Railroad Engine House Facility Management and Interpretive Plan" should be used to guide the development of interpretive programming for the Engine House Facility. It is important to place the facility within context of the Keweenaw Copper District, demonstrating the vital role that transportation systems, particularly railroads, played in supporting Michigan's copper industry. These systems not only tied the components of production together, but also permitted year round access to the district.

Continued restoration work at the Engine House Facility presents several interpretive opportunities to expose QMHA visitors to the site. For example, an interpretive walking trail has been designed with the intent of moving visitors from the main exhibit area to the engine house site. This walking tour will utilize interpretive panels placed at key locations along the path to place the railroad within context of QMHA tours (text examples appear as an appendix).

Other interpretive opportunities are present and can be developed to highlight ongoing restoration work at the facility. For example, historic building techniques can be demonstrated during stabilization and restoration work on structures and historic use of the facility can demonstrate historic use of the structure. The following will help guide the process of development and implementation.

\section{Interpretation}

"An educational activity which aims to reveal meaning and relationships through the use of original objects, by firsthand experience, and by illustrative media, rather than simply to communicate factual information." (Tilden, 1957; page 8)

Facts are the intellectual components of interpretation and while important, lack meaning if presented in the absence of emotion. The glazed-eye stares of tourists receiving a litany of dates and technical information can attest to that truth. Properly 
done, interpretation will help visitors connect with the significance of places, events, people, and things. They are not just learning about something, but should be experiencing it. Interpretation should engage visitors and make them think about things in new ways, make them think about their surroundings, the environment around them, the park, the exhibit, and the objects on display. Everything a visitor does, thinks, senses, and feels on the exhibit grounds constitutes their "park experience"(Planning 1998). Interpretive planning seeks to create that experience and describes ways to encourage those experiences through various forms of media, such as wayside panels, guided tours, or formal programs and presentations. It connects the tangible with the intangible and uses emotion to do it. To clarify, consider the following:

Tangible:

Poor rock from Quincy mine's waste rock piles was used to build the Q\&TLRR engine house.

Connecting with the intangible:

Craftsmen, largely European immigrants seeking a better life in America, handpicked and skillfully shaped and placed stones gleaned from the mine's waste rock piles to construct an engine facility where steam locomotives purchased by the rapidly expanding mining company were stored and maintained. The structure was altered over time to accommodate an increasing fleet of engines and still stands after 120 years, attesting to the care and pride possessed by the stone masons, whose skills and traditions were honed through the centuries on the walls of great European cathedrals and modest stone dwellings.

The Engine House interpretive plan outlines how resources can be used to tell the story of the Q\&TLRR and its engine facility and helps identify which stories to tell through interpretive themes and how to convey that information through interpretive media, reaching the widest possible audience. 


\section{Interpretive and Thematic Objectives}

Thematic objectives, provide a framework to help management gauge the success of an interpretive program. After visiting QMHA's industrial heritage site, visitors should be able to:

- Identify the significance of the railroad to Quincy Mining Company's overall success.

- Identify and explain the railroad's role in the mining environment.

- Identify and explain major components of the railroad.

- Identify and explain major elements of the engine house facility.

- Identify and explain major activities taking place at the facility.

- Identify the workforce and their role at the engine facility and on the railroad.

- Identify similarities between the Q\&TLRR and other railroads.

- Understand operational principles of steam locomotives.

- Maintain a consistent vision even as staff members change.

- Enhance training of new employees by ensuring a consistent message.

- Enhance visitor experience by connecting them with the industrial heritage of the Quincy Mining Company.

- Convey the importance of reliable transportation to the successful operation of the mining company.

- Provide visitors with the tools to then apply that knowledge to their own experience.

- Promote the Q\&TLRR Engine House Facility as a vital feature within the industrial landscape at the Quincy Mine.

\section{Interpretive Themes}

Interpretive themes summarize the principal message to be conveyed to visitors at the site and are drawn from the Statements of Significance. Interpretive themes also limit the tendency simply to present a list of loosely related facts by focusing the story to be told upon contents of the theme. Themes should engage and grab the audience's attention. 
They reveal the overall direction of interpretation at the site to provide the visitor with a memorable experience.

While many visitors to the site may possess some knowledge of our nation's industrial heritage, others will be unfamiliar with many aspects of it. This interpretive program should guide those visitors through the unfamiliar information and topics with straight forward and simple explanations.

\section{Primary Theme}

Transportation was a vital component of copper production in the Keweenaw Peninsula, and Quincy Mining Company's Engine House Facility provides an opportunity for visitors to experience an aspect of the diverse work environment of Michigan's copper mining district.

\section{Sub-Themes}

- Labor's diversity is demonstrated in the various components of the Engine House's construction and furnishings, illustrating the variety of skills required to maintain the systemic components of the mine.

- Labor, machines, and management are fragile components of industry; if any fail to perform as expected, the mechanism of production is interrupted and system wide failure can occur. Therefore, maintenance and repairs are critical at key points in the work and production flow.

- Railroads were essential to many mining operations in Michigan's copper district and represent a high degree of investment, efficiency, and self-reliance.

Additional interpretive themes may be created for specific presentations or programs for the site and can be created by using the Statements of Significance and the above themes as examples. New themes can be developed for new interpretive displays or additional interpretive panels at other locations at which transportation components need to be addressed, for example, the Number 2 Shafthouse. 


\section{Visitor Profile}

An accurate visitor profile will help determine visitor needs and will enable exhibit designers to fine tune interpretive programs. Keweenaw National Historical Park conducted and published a visitor study in 2004. The study-group distributed 565 questionnaires at twelve of the Park's seventeen cooperating heritage sites (92 questionnaires were distributed at Quincy), and 403 of the surveys were returned. Three hundred ninety-six visitor groups, numbering 1 to 5 or more per group represented more than 1400 individuals. "Families" was the single largest group. Other groups included educational, elder hostel, senior tour groups, and boat tours. More than $60 \%$ of park visitors were 36 and older, and $24 \%$ of the visitors were under the age of 16 . Nine percent of the visiting groups had at least one member with disabilities (mobility, hearing, hemiplegics, allergies), and nearly half of those encountered accessibility barriers. A quarter of the respondents had visited the Keweenaw before, and more than $75 \%$ were from Michigan and Wisconsin. The Keweenaw National Historical Park Visitor Study (2004) shows the top five states of visitor origin border Michigan.

QMHA Scheduled Tour records provide insight into Quincy visitor groups, though specific demographic information is not part of that record. Quincy tour schedules indicate the following groups:

- Church and youth groups.

- School groups from grade school through university age.

- Special interest groups, including automobile, motorcycle, and mobile home associations.

- Academic and organizational groups, such as geology, library professionals, and mining engineers.

- Political dignitaries.

- Family or tour groups from other countries, most frequently Canada and Finland, 
though visitors from the UK and Germany are also common.

The KNHP visitor study indicates that the primary reason that tourists visit the Keweenaw was family and recreation related. Other reasons for their visit included: visiting one or both of the national parks, to learn about copper mining history, business, university visits, and interests in genealogy. The most common experiences included the following activities: visiting historic sites and ruins, gift shops, national parks and cooperating sites, lighthouses, Quincy Mine site, theater performances, hiking, picnicking, viewing wild life and birding, and camping.

\section{Visitor Experience}

By visiting the Engine House Facility the visitor should have the available opportunities or experiences if the interpretive program is successfully implemented:

- To enjoy and experience the industrial landscape and gain a better understanding of the QMHA exhibits.

- To synchronize or personalize tours on their own of the wider Quincy mine complex.

- To explore and discover Quincy Mining Company history.

- To learn how transportation contributed to the success of the Quincy Mining Companty.

- To learn about the railroad's role in a mining environment.

- To learn about the daily activities performed at the engine facility and on the railroad, and about the men who kept the railroad going.

- To experience the engine facility, the equipment, and the environment of a steam-era railroad.

- To compare personal experiences of daily life with that of a bygone era.

- To contrast the Q\&TLRR with their own railroad experiences or encounters.

- To attend special railroad themed programs and events.

- To experience working steam engines and contemporary equipment, such as steam tractors and antique engines and machinery, through special events hosted by QMHA at 
the engine facility.

\section{Engine House Facility Interpretive Trail}

Heather Spencer's “Quincy Mine National Historic Landmark Interpretive Trail System" (1995), provided to the Quincy Mine Hoist Association a thorough plan for developing an interpretive hiking, biking, and walking trail system around QMHA's exhibit complex. The plan has not been implemented. However, new interpretive trail planning can utilize that work as a guide to implement future trail based tours. In addition the Keweenaw National Historical Park has proposed the creation of multi-use trails within the Quincy Unit of the park. These projects are discussed in the "Quincy Mine Historic Landscape Cultural Landscape Report and Environmental Assessment" (2010) in chapter 8. It is recommended that a trail be developed for use by QMHA visitors to expose and provide access to the engine house facility. This should be a priority.

Any trail between the No 2 hoist house exhibit and the Quincy \& Torch Lake Railroad engine house exhibit should follow a former transportation route (Figure 24) used by the mining company. Following one of the mining company's old railroad grades (Routes A and B) will enhance visitor experience and understanding by moving them along the same path that rock and fuel followed between the mine and mill. Alternatively, implementing a portion of Spencer's planned "Hiking Trail"(Route C), will allow visitors to move through the Quincy No. 4 area ruins on their way to the engine house, creating additional interpretation opportunities (1995, 31-34). That trail follows a short section of Quincy's early tram road route (Figure 25).

The construction of a walking path between the No. 2 hoist house and the engine house facility can take place in phases as funding permits. All three proposed routes will require a minimum of brushing and clearing of debris and subsequent phases may include refining the trail by creating a hard packed surface the length of the trail. It is 


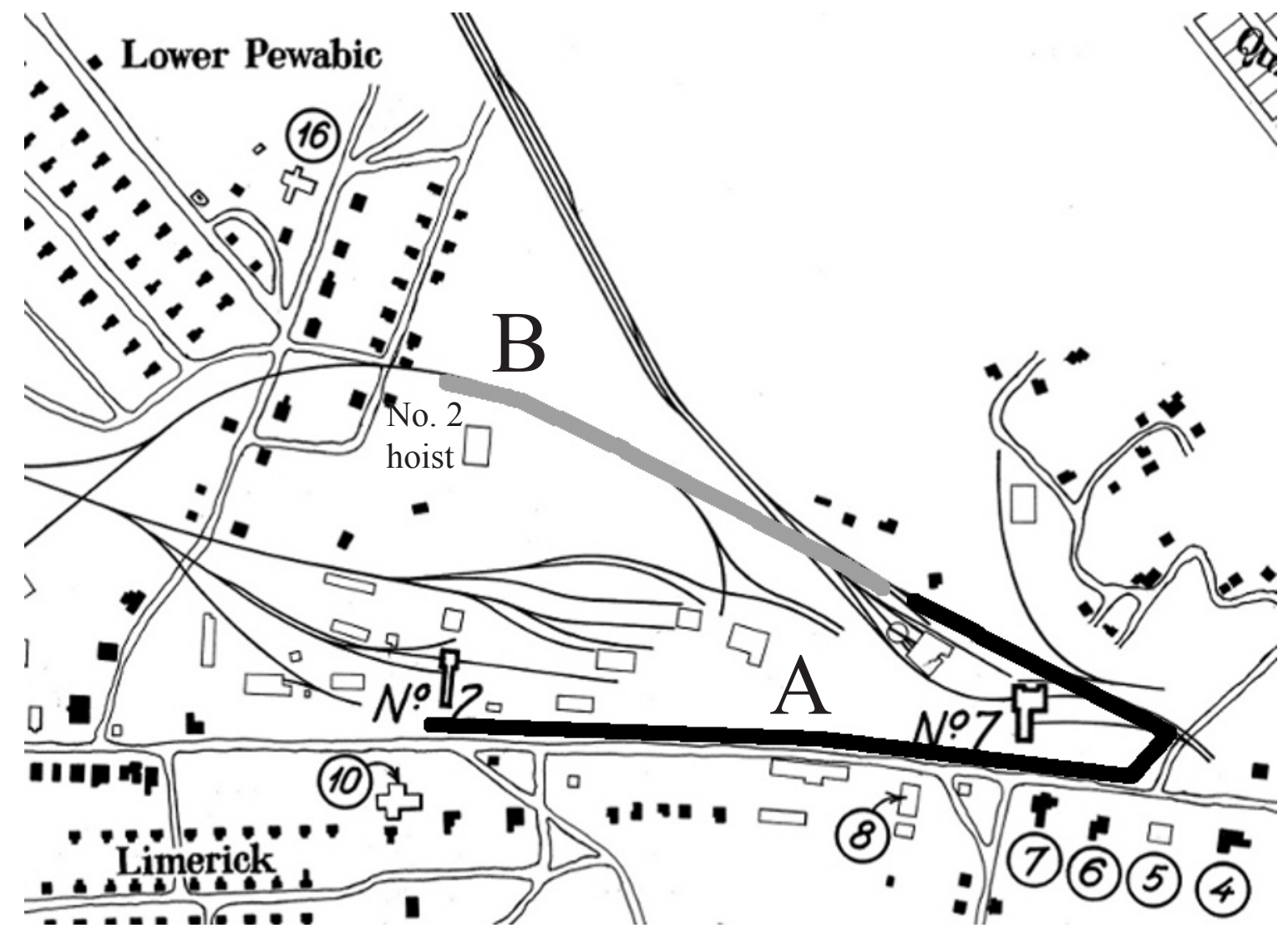

Figure 24. Map detail, showing location proposed walking trails A and B. Excerpted from “Quincy Mine Location, Housing and Community Structures." Sheet 7 of 34. Historic American Engineering Record, Heritage Conservation and Recreation Service, National Park Service, U.S. Department of the Interior. Delineated by Edward Potter, Jr., 1978. 


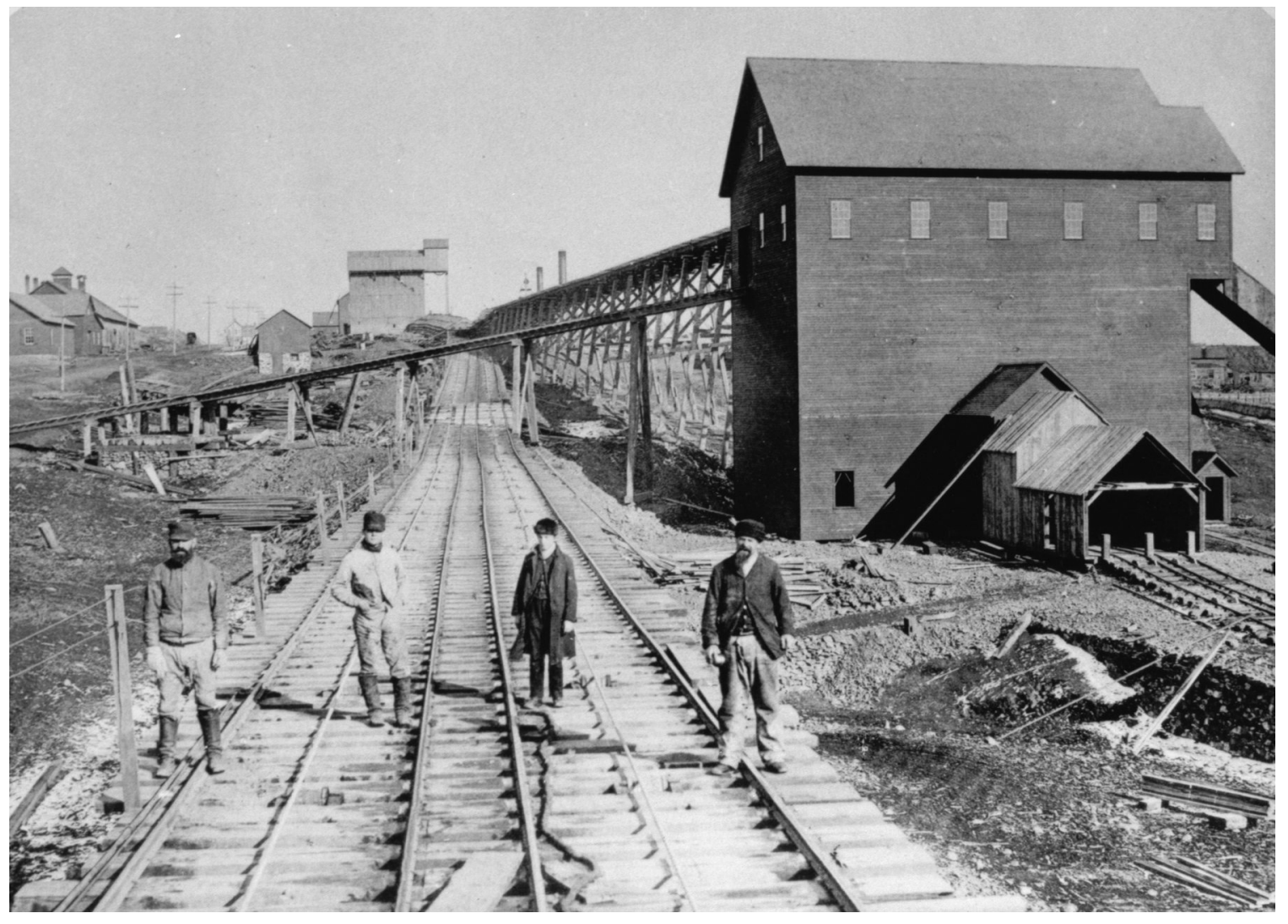

Figure 25. Quincy Mining Company tram road. In the distance on the left is the blacksmith shop, distant middle the No. 4 shaft house, and close right is the Quincy rock house. This tram road continues on to Quincy's stamp mill on Portage Lake, Hancock, Michigan. Photo courtesy Historic American Engineering Record, HAER MI-2-71. 
recommended that the Quincy Mine Hoist Association work closely with an engineering firm and the Keweenaw National Historical Park when designing and developing any trails on the site to assure compliance with state and federal requirements.

\section{Outcomes and Further Options}

The interpretive trail plan is necessary. It will open the site up to visitors and further development of the engine house exhibit will enhance visitor experience by providing a connection between the mine and mills, the movement of copper rock and fuel, and develop a deeper understanding of the components of the overall production process. Visitors can also be made aware of opportunities available at the Quincy \& Torch Lake Railroad engine facility through the web and advertising. However, most will be informed of the facility for the first time upon arrival at the QMHA site and will be made aware of the engine house facility as part of the overall exhibit experience. The following section highlights several possibilities to increase the engine house facility's visibility.

\section{Before Arriving}

There are a number of ways to reach a prospective audience and alert them about the engine facility:

- Include the engine facility on brochures as an exhibit opportunity offered by QMHA.

- Gift shop should include the engine house facility in site description and tour opportunities available to visitors.

- Main exhibit and tours should include the railroad in existing interpretation.

- Visitors should hear about railroad exhibit at participating KNHP partner heritage sites.

- Web presence can inform visitors of the site.

- Advertise in railroad history and hobby publications.

\section{Engine House}

Implementation of guided/self-guided tours at engine facility:

- Tour guides (if staffed) should make visitors feel welcome and provide orientation. 
- Should make it clear that visitors are invited to explore the site.

- Should be provided with opportunities to make discoveries on their own.

- Tours and waysides should complement each other, and follow thematic design.

- Interpretation should provide visitor with clues to assemble the overall picture and make connections between the larger concepts on their own.

- Tours and exhibits should be uncluttered and easy to understand.

- Visitors should be given an opportunity to ask questions and provide feedback.

\section{Further Options}

Available interpretive opportunities:

- Staged equipment displays: locomotive and cars at various locations, swapping with equipment stored in engine house.

- Hosting annual antique engine show to provide live demonstrations of steam and contemporary equipment at engine facility.

- Demonstration of historic skills utilized at engine facility, such as carpentry and blacksmithing. 


\section{Conclusion}

The Quincy Mine Hoist Association works to preserve the Quincy Mining Company's legacy, and occupies a prominent leadership position in efforts to preserve and interpret the industrial heritage of Michigan's Copper District. Work initiated 10 years ago began to materialize in 2009 at the Engine House Facility. This work is a long term process and will take years to fully materialize. This document should guide that process and be periodically reviewed kept up to date.

As QMHA grows and continues to develop exhibit and interpretive programing, a formal document to guide that work has become necessary. The "Quincy \& Torch Lake Railroad Management and Interpretive Plan" is the result of that realization. This document is the starting point for future planning. It is a guide, by design, for a larger management and interpretive plan and should encompass the entire Quincy Mining Company Landmark District. 


\section{Bibliography}

Beck, Larry, and Ted Cable. 2002. "Interpretation for the 21 st Century: Fifteen Guiding Principles for Interpreting Nature and Culture." Sagamore Publishing, Champaign, IL.

Edwards, Curtis. 1994. "Interpretive Project Guide Book: A Region 6 Interpretive Services Aid.” U.S.D.A. Forest Service, Pacific Northwest Region. http:// www.fs.fed.us/outdoors/naturewatch/start/planning/Interp-Guidebook.pdf

Heritage Lottery Fund 2009. "Thinking about Interpretation.” http://www.hlf.org.uk HowToApply/furtherresources/Documents/Thinking_about_interpretation.pdf

Hoagland, Alison K., Erik C. Nordberg, and Terry Reynolds. 2007. "New Perspectives on Michigan's Copper Country.” Quincy Mine Hoist Association, Hancock Michigan.

International Council on Monuments and Sites. 2008. "The ICOMOS Charter for the Interpretation and Presentation of Cultural Heritage Sites" http:// www.enamecharter.org/downloads/ICOMOS_Interpretation_Charter_EN_10-0407.pdf

Knapp, Doug, and Gregory M. Benton. 2004. "Elements to Successful Interpretation: A Multiple Case Study of Five National Parks.” Journal of Interpretation Research. $9 / 2$ http://www.interpnet.com/JIR/pdf/JIR-v9n2.pdf

Kohen, Richard, and Kim Sikoryak. 2005. "CIP Guide: A Guide to Comprehensive Interpretive Planning." Essential Tools for Interpreters. Office of Interpretation and Education, Intermountain Region. U. S. Department of the Interior, National Park Service.

Lancaster County Planning Commission. "Telling Our Stories: An Interpretation Manual for Heritage Partners.” Lancaster County Planning Commission, Lancaster County, PA. http://www.co.lancaster.pa.us/lancheritage/lib/lancheritage/pubs/file_3, interpretation_manual.pdf

Lankton, Larry D. and Charles K. Hyde. 1982. "Old Reliable: An Illustrated History of the Quincy Mining Company.” Quincy Mine Hoist Association, Hancock Michigan.

Larson, David. "Interpretive Themes." U.S. Department of the Interior, National Park Service. http://www.nps.gov/idp/interp/101/themes.pdf

Leftridge, Alan. 2006. "Interpretive Writing." The National Association for Interpretation. Fort Collins, CO. 
O'Connell, Charles F. 1978. "A History of the Quincy and Torch Lake Railroad Company, c. 1888-1927." An unpublished report produced for the Historic American Engineering Record.

Pomazal, Charles. 1991. “The Quincy \& Torch Lake Engine House.” Narrow Gauge and Short Line Gazette, June/July.

Spencer, Heather L. 1995. "Quincy Mine National Historic Landmark Interpretive Trail System” Masters Thesis, Michigan Technological University.

Sung, W. Kim. 2006. "Interpretation Plan for the Dr. Philip Jaisohn Memorial House." Masters Thesis, University of Pennsylvania.

Tilden, Freeman. 1977. “Interpreting Our Heritage.” Chapel Hill: University of North Carolina Press.

Veeser, W. to John Caspary, personal correspondence. December 19, 1966.

Wilson, Craig P. 2010. “Archaeological Investigations and Preliminary Recommendations for Rehabilitation at the Quincy \& Torch Lake Railroad Engine House, Quincy Mine, Hancock, Michigan." Unpublished report submitted to the Quincy Mine Hoist Association.

Wilson, Craig P. 2010. "From Ruin to Museum: Preserving and Interpreting the Quincy \& Torch Lake Railroad Engine House.” Masters Thesis, Michigan Technological University.

Unattributed National Park Service and Other Publications

“By-laws” 1958. Quincy Mine Hoist Association.

“Components of a Successful National Heritage Area Management Plan.” U.S. Department of the Interior, National Park Service. 2007. http://www.nps.gov/ history/heritageareas/REP/notebook.pdf

“Comprehensive Interpretive Planning." U.S. Department of the Interior, National Park Service. http://www.nps.gov/hfc/pdf/ip/cip-guideline.pdf

"HANCOCK_SW.ecw" 2007 Michigan Georef NAIP Digital Ortho Photo Image, Remote Sensing \& GIS Research and Outreach Services (RS\&GIS), Michigan State University. Accessed April 8, 2011. http://www.mcgi.state.mi.us/doqqviewer 
"Interp Guide: The Philosophy and Practice of Connecting People to Heritage." Essential Tools for Interpreters. Office of Interpretation and Education, Intermountain Region. U. S. Department of the Interior, National Park Service. 2005.

"Illustrated Guidelines for Rehabilitating Historic Buildings." 2011 National Park Service, Department of the Interior. Accessed April 28. http://www.nps.gov/hps/tps/ $\operatorname{tax} / \mathrm{rhb}$

"Keweenaw National Historical Park Visitor Study, Summer 2004." Visitor Services Project Report 158. U.S Department of the Interior, National Park Service. 2005.

"Planning for Interpretation and Visitor Experience." U.S. Department of the Interior, National Park Service. Harpers Ferry, West Virginia. 1998 http://www.nps.gov/hfc/ pdf/ip/interp-visitor-exper.pdf

"Preparing a Heritage Management Plan.” Natural England http://naturalengland.etraders tores.com/NaturalEnglandShop/NE63

"Quincy Mine Historic Landscape, Cultural Landscape Report and Environmental Assessment.” U.S. Department of the Interior, National Park Service. 2010 


\section{Appendices}

\section{Interpretive Panels}

The following nine text blocks are provided as examples of texts for interpretive panels that may be used in developing the initial interpretive program at the engine house. The choice of panel and its placement within the structure will depend on program planning. It is recommended that an orientation panel be developed and placed at the facility as soon as possible.

\section{You Are Here}

The engine facility was the heart of the railroad's operations and was located here to provide convenient access to both the mine branch and to the main line and yard serving the mill. The Quincy \& Torch Lake Railroad linked the mine with the company's stamp mills, six miles away, on Torch Lake.

\section{Stables for the Iron Horse}

Craftsmen, largely European immigrants, skillfully handpicked and shaped stones gleaned from the mine's waste rock piles to build the railroad's engine house. The structure was altered several times over the years to accommodate more locomotives and provide shop space, providing a full range of the personnel, machinery, and hand tools required to maintain the railroad's locomotives and freight cars.

3. Early Risers. "You're late at 7:00am"

A typical shift on the Quincy \& Torch Lake Railroad began at 6:30am. Men reported to the engine house in the morning, working a full day in 8-to-12 hour shifts. Blacksmiths, 
machinists, engine wipers, and car repairers spent their work day repairing and performing routine maintenance on the railroad's equipment and had at their disposal the necessary tools to do that work.

\section{Running a Railroad}

The Quincy \& Torch Lake Railroad was one of many small, dependent mining company railroads found throughout the Keweenaw Peninsula in the early $20^{\text {th }}$ century. It shared many common with its nearby neighbors and larger national cousins. Like other local railroads Quincy maintained a large fleet of dedicated rock cars that did double duty, hauling rock to the mill and coal to the mine. It also had a small fleet of cabooses.

\section{How It Works}

This panel will illustrate the science behind a simple steam engine to help visitors understand the inner working of a steam locomotive.

\section{Keeping it Going}

The engine house and railroad were as busy as the mine and mill in the race to keep the flow of rock and coal running smoothly. Men on the trains and in the shop orchestrated the operation of the railroad to time repair work with slow periods. They worked quickly to ensure engines and cars returned to service with as little down time as possible. 
7. Then and Now.

The Quincy Mining Company fostered a certain level of corporate pride throughout its existence and even after suspending work in the mine, the company hoped that it would again reopen. That hope contributed to the preservation of the site.

\section{Never a Wasted Trip}

Quincy \& Torch Lake Railroad raced to keep the mine's rock bins empty and its hungry boilers fed. Few trips were wasted, and nearly every train to the mill meant a return trip loaded with coal for the hoist's boilers from the docks on Torch Lake. Carrying roughly 18 tons each, a twenty car train was able to haul 360 tons of coal, equivalent to four loaded train cars today!

9. Steam, Coal, and Copper Rock.

Railroads served a vital role in Michigan's copper industry, feeding the industrial growth of the nation with continuous supplies of copper-laden rock and bringing deep black coal to the mines to be consumed in the blazing infernos of the boilers that drove the mine, pumps, hoists, and locomotives. 